*akls View/Frint Document Cover Sheet tow

This document was retrieved from the Boeing ISEARCH System.

Accession \#: D196054631

Document \#: SD-WM-ER-439

Title/Desc:

TANK 241BX104 HEADPSACE GAS \& VAPOR CHARACTERIZATION RESULTS FOR SAMPLES COLLECTED IN $12 / 1994$ 


\begin{tabular}{|c|c|c|c|c|c|c|}
\hline \multirow{3}{*}{$\begin{array}{l}\text { 2. ECN Category } \\
\text { (mark one) } \\
\text { Suppl emental } \\
\text { Direct Revision } \\
\text { Change ECN } \\
\text { Temporary } \\
\text { Standby } \\
\text { Supersedure } \\
\text { Cancel/Void }\end{array}$} & \multirow{3}{*}{$\begin{array}{l}{[]} \\
{[1]} \\
{[]} \\
{[]} \\
{[]}\end{array}$} & \multicolumn{2}{|c|}{$\begin{array}{l}\text { 3. Originator's Name, Organization, MSIN, } \\
\text { and Telephone No. } \\
\text { D. R. BRATZEL, 75640, S7-21, } \\
\text { 373-3579 }\end{array}$} & \multicolumn{2}{|c|}{$\begin{array}{l}\text { 3a. USQ Required? } \\
\text { [] Yes [X] No }\end{array}$} & $\begin{array}{l}\text { 4. Date } \\
09 / 27 / 95\end{array}$ \\
\hline & & \multicolumn{2}{|c|}{$\begin{array}{l}\text { 5. Project title/Ho./Work order No. } \\
\text { TANK 241-BX-104 HEADSPACE GAS } \\
\text { AND VAPOR CHARACTERIZATION } \\
\text { RESULTS FOR SAMPLES COLLECTED } \\
\text { IN DECEMBER 1994 }\end{array}$} & \multicolumn{2}{|c|}{$\begin{array}{l}\text { 6. Bldg./Sys./Fac. No. } \\
2704 \mathrm{HW} / 200 \mathrm{E}\end{array}$} & $\begin{array}{l}\text { 7. Approval Designator } \\
\qquad N / A\end{array}$ \\
\hline & & \multicolumn{2}{|c|}{$\begin{array}{l}\text { 8. Document Numbers Changed by this ECW } \\
\text { (includes sheet no. and rev.) } \\
\text { WHC-SD-WM-ER-439 REV } Y O\end{array}$} & $\begin{array}{l}\text { 9. Relat } \\
8 / 95\end{array}$ & CN No(s). & $\begin{array}{l}\text { 10. Related PO No. } \\
\qquad N / A\end{array}$ \\
\hline \multirow{2}{*}{\multicolumn{2}{|c|}{$\begin{array}{l}\text { 11a. Modification Work } \\
\text { [] Yes (fill out Blk. } \\
11 \mathrm{~b} \text { ) } \\
{[X] \text { No (NA Blks. 11b, }} \\
11 \mathrm{c}, 11 \mathrm{~d})\end{array}$}} & \multirow[t]{2}{*}{$\begin{array}{l}\text { 11b. Work Package } \\
\text { No. } \\
N / A\end{array}$} & \multirow{2}{*}{\multicolumn{2}{|c|}{$\begin{array}{l}\text { 11c. Modification Work Complete } \\
N / A\end{array}$}} & \multicolumn{2}{|c|}{$\begin{array}{l}\text { 11d. Restored to Original Condi- } \\
\text { tion (Temp. or Standloy ECN only) } \\
\text { N/A }\end{array}$} \\
\hline & & & & & Cog. & eer signa \\
\hline
\end{tabular}

12. Description of Change

Title change and complete rewrite.

13a. Justification (mark one)

$\begin{array}{lllllll}\text { Criteria Change } & {[X]} & \text { Design Improvement } & {[]} & \text { Environmental } & \text { [] } & \text { Facility Deactivation } \\ \text { As-Found } & {[]} & \text { Facilitate Const } & \text { [] } & \text { Const. Error/Omission } & \text { [] } & \text { Design Error/Omission }\end{array}$

13b. Justification Details

Complete rewrite which includes all vapor sampling events to date and data qual ification.

14. Distribution (include name, MSIN, and no. of copies)

See attached Distribution Sheet
RELEASE STAMP

OFFICIAL RELEASE BY WHC

DATE SEP 281995

524 


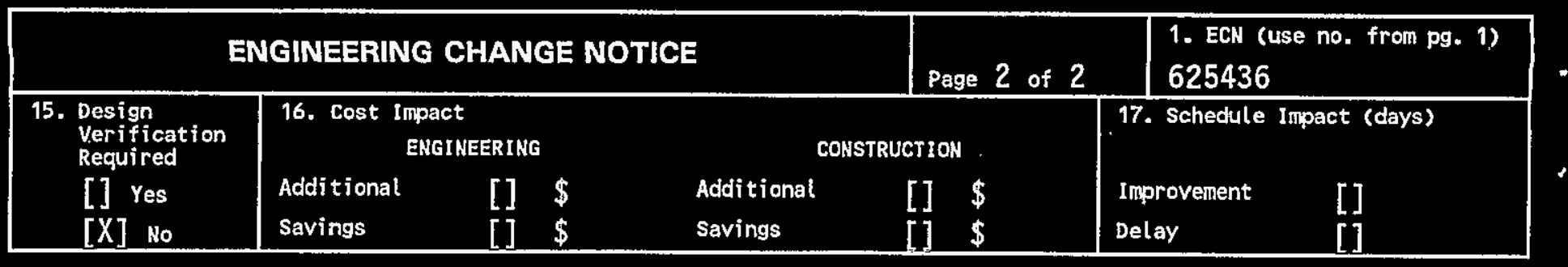

18. Change Impact Review: Indicate the related documents (other than the engineering documents identified on Side 1) that will be affected by the change described in Block 12 . Enter the affected document number in Block 19.

$\begin{array}{ll}\text { SDD/DD } & {[]} \\ \text { Functional Design Criteria } & \\ \text { Operating Specitication } & \\ \text { Criticality Specification } & \\ \text { Conceptual Design Report } & \\ \text { Equipment Spec. } & \\ \text { Const. Spec. } & {[]} \\ \text { Procurement Spec. } & {[]} \\ \text { Vendor information } & {[]} \\ \text { OM Manual } & {[]} \\ \text { FSAR/SAR } & {[]} \\ \text { Safety Equipment List } & {[]} \\ \text { Radiation Work Permit } & {[]} \\ \text { Environmental impact Statemont } & {[]} \\ \text { Environmental Report } & {[]} \\ \text { Environmental Permit } & \end{array}$

[] Seismic/Stress Analysis

[] Tank Calibration Manual

[] Stress/Design Report

[] Interface Control Drawing

[]

[] Calibration Procedure

[]

[]

Installation Procedure

[]

[] Maintenance Procedure

[]

[]

Engineering Procedure

[]

[]

[]

Operating Instruction

[]]

Operating Procedure

[]

[]

Operational Safety Requirement

[]

IEFD Drawing

[]

Cell Arrangement Drawing

[]

Essential Materiał Specification

[]

Fac. Proc. Samp. Schedule

[]

Inspection Plan

[]

Inventory Adjustment Request

Tank Calibration Manual
Health Physics Procedure

Spares Multiple Unit Listing

Test Procedures/Specification

Component index

ASME Coded Item

Human Factor Consideration

Computer Software

Electric Circuit Schedule

ICRS Procedure

Process Control Manual/Plan

Process Flow Chart

Purchase Requisition

Tickler File

$\begin{array}{lll}{[]} & \text { Fac. Proc. Samp. Schedule } & \text { [] } \\ {[]} & \text { inspection Plan } & {[]} \\ {[]} & \text { Inventory Adjustment Request } & \text { [] }\end{array}$

19. Other Affected Documents: (NOTE: Documents Listed below will not be revised by this ECN.) Signatures below indicate that the signing organization has been notified of other affected documents listed below. Document Number/Revision

20. Approvals

signature OPERATIONS AND ENGINEERING

Cog. Eng. D. R. Bratzel

Cog. Mgr. T. J. Kelley

QA

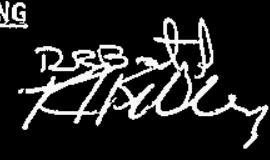

Safety

Environ.

other

Proj.

Proj.

Proj.

Proj.

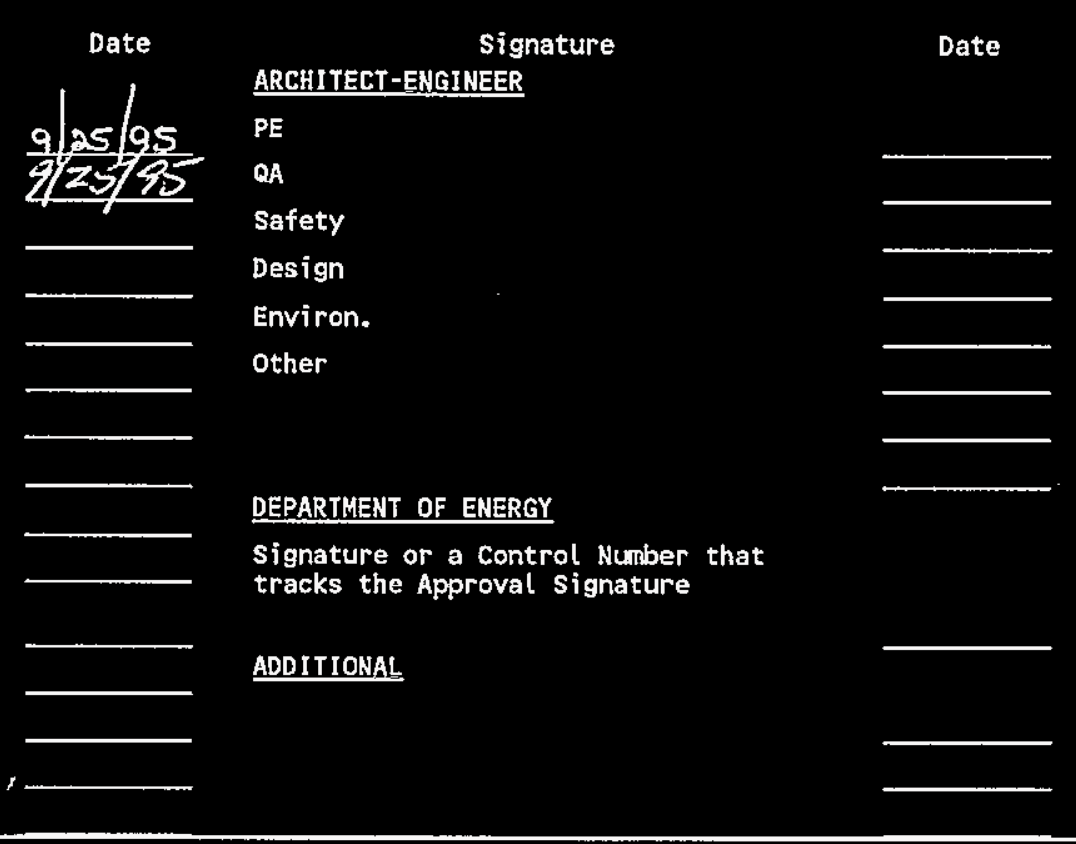




\section{RELEASE AUTHORIZATION}

\begin{tabular}{|ll|}
\hline Document Number: & WHC-SD-WM-ER-439, REV 1 \\
\hline Document Title: & $\begin{array}{l}\text { Tank 241-BX-104 Headspace Gas and Vapor } \\
\text { Characterization Results for Samples Collected in } \\
\text { December 1994 }\end{array}$ \\
\hline Release Date: & $9 / 28 / 95$ \\
\hline
\end{tabular}

This document was reviewed following the procedures described in WHC-CM-3-4 and is:

\section{APPROVED FOR PUBLIC RELEASE}

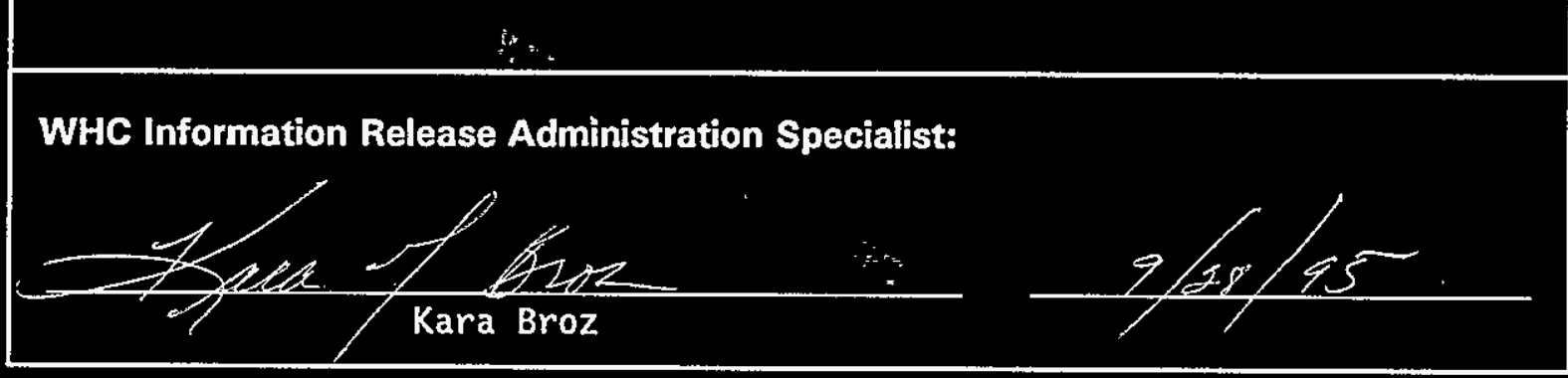

TRADEMARK DISCLAIMER. Reference herein to any specific commercial product, process, or service by trade name, trademark, manufacturer, or otherwise, does not necessarily constitute or imply its endorsement, recommendation, or favoring by the United States Government or any agency thereof or its contractors or subcontractors.

This report has been reproduced from the best available copy. Available in paper copy. Printed in the United States of America. To obtain copies of this report, contact:

Westinghouse Hanford Company - Document Control Services

P.0. Box 1970, Mailstop H6-08, Richland, WA 99352

Telephone: (509) 372-2420; Fax: (509) 376-4989 


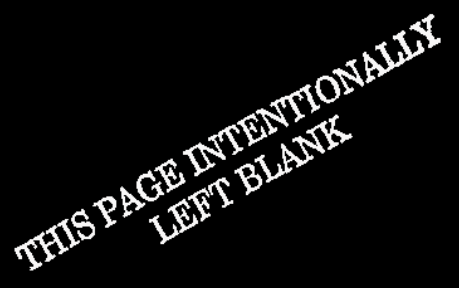


2. Title

TANK 241-BX-104 HEADSPACE GAS AND VAPOR

CHARACTERIZATION RESULTS FOR SAMPLES COLLECTED IN DECEMBER 1994

5. Key Words

CHARACTERIZATION OBJECTIVES, TANK HEADSPACE, SAMPLING EVENT, INORGANIC GASES, ORGANIC VAPORS
3. Number

WHC-SD-W W
4. Rev No.

1
6. Author

Name: D. R. BRATZEL

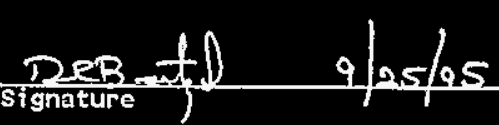

Organization/Charge Code

$75640 / \mathrm{N} 4 \mathrm{ABI}$

\section{Abstract}

Significant changes have been made to all of the original vapor characterization reports. This report documents specific headspace gas and vapor characterization results for all vapor sampling events to date. In addition, changes have been made to the original vapor reports to qualify the data based on quality assurance issues associated with the performing laboratories. 


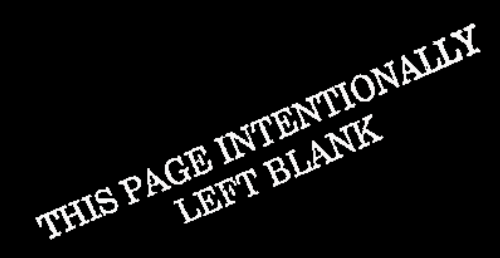




\begin{tabular}{|c|c|c|c|c|}
\hline \multicolumn{2}{|r|}{ RECORD OF REVISION } & \multicolumn{2}{|c|}{$\begin{array}{l}\text { (1) Document Number } \\
\text { WHC-SD-WM-ER-439 }\end{array}$} & Page 1 \\
\hline \multicolumn{5}{|c|}{$\begin{array}{l}\text { (2) Title } \\
\text { TANK 241-BX-104 HEADSPACE GAS AND VAPOR CHARACTERIZATION RESULTS FOR SAMPLES COLLECTED } \\
\text { IN DECEMBER } 1994\end{array}$} \\
\hline \multicolumn{5}{|c|}{ CHAMGE CONTROL RECORD } \\
\hline (3) Revision & (4) Description of Change - Replace, Add, and Delete Pages & \multicolumn{3}{|c|}{ Authorized for Release } \\
\hline 0 & $\begin{array}{l}\text { (7) WHC-SD-WM-ER-439, REV. 0, EDT } 612331 \\
\text { May 31, 1995 }\end{array}$ & (5) Cog. Engr. & (6) $\mathrm{c}$ & gr. Date \\
\hline 1 RES & $\begin{array}{l}\text { Complete revision and title change. ECN } \\
625436\end{array}$ & f) & & \\
\hline & & & & \\
\hline & & & & \\
\hline & & & & \\
\hline & & & & \\
\hline & & & & \\
\hline & & & & \\
\hline & & & & \\
\hline & & & & \\
\hline & & & & \\
\hline & & & . & \\
\hline & & & & \\
\hline & & & & \\
\hline & & & & \\
\hline
\end{tabular}




$$
\not
$$




\title{
Tank 241-BX-104 Headspace Gas and Vapor Characterization Results for Samples Collected in December 1994
}

\author{
J. L. Huckaby \\ Pacific Northwest Laboratories \\ D. R. Bratzel \\ Westinghouse Hanford Company
}

Date Published

September 1995

Prepared for the U.S. Department of Energy

Office of Environmental Restoration and

Waste Management

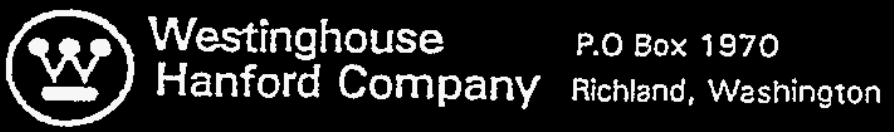

Management and Operations Contractor for the

U.S. Department of Energy under Contract DE.ACD6-87FL 10930 



\section{Contents}

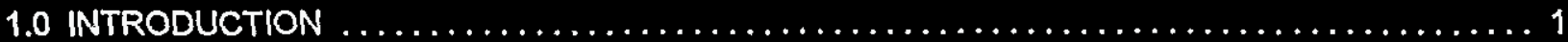

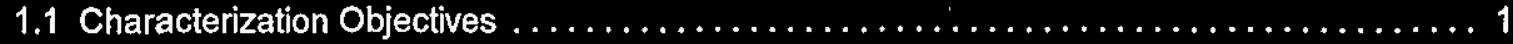

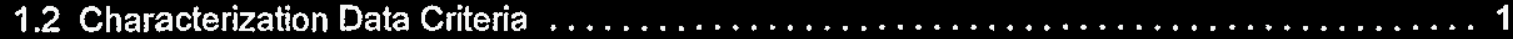

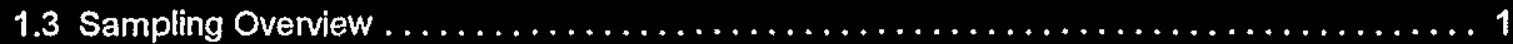

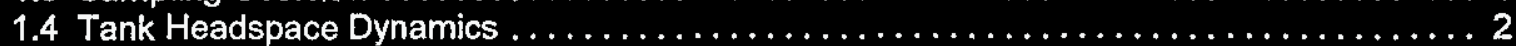

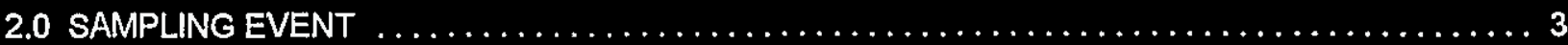

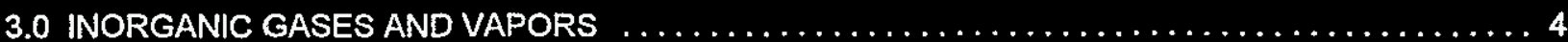

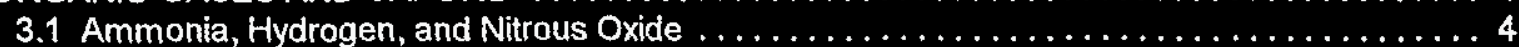

3.2 Carbon Monoxide and Carbon Dioxide .............................. 4

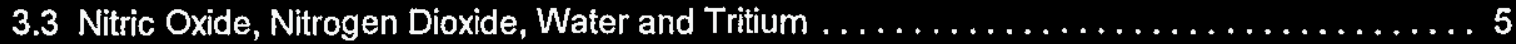

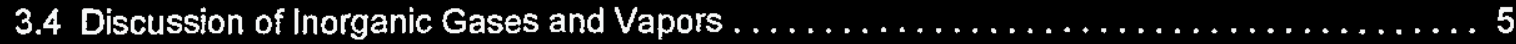

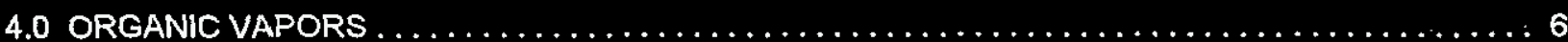

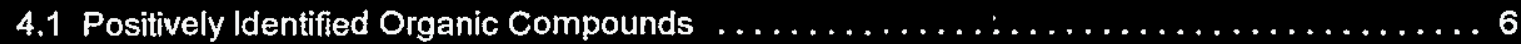

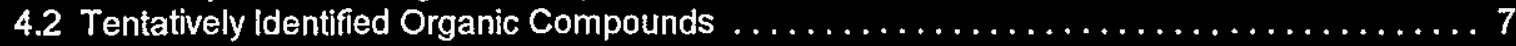

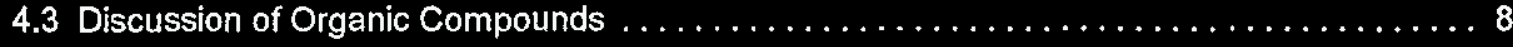

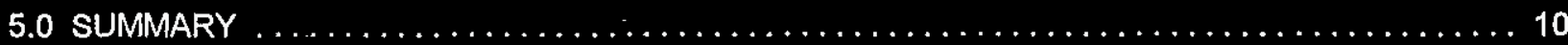

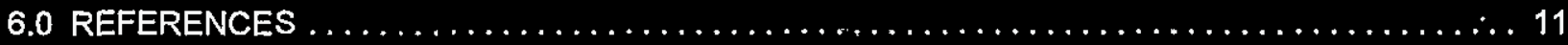

Acronyms and Abbreviations

$\begin{array}{ll}\text { CES } & \text { consensus exposure standard } \\ \text { EPA } & \text { Environmental Protection Agency } \\ \text { GC } & \text { gas chromatograph } \\ \text { GCMS } & \text { gas chromatograph/mass spectrometer } \\ \text { LFL } & \text { lower flammability limit } \\ \text { MS } & \text { mass spectrometer } \\ \text { NFPA } & \text { National Fire Protection Association } \\ \text { NPH } & \text { normal paraffinic hydrocarbon } \\ \text { ORNL } & \text { Oak Ridge National Laboratory } \\ \text { PNL } & \text { Pacific Northwest Laboratory } \\ \text { ppmv } & \text { parts per million by volume, } 1 \text { ppmv }=10^{-4} \text { vol\% } \\ \text { TST } & \text { triple sorbent trap } \\ \text { vol\% } & \text { percent by volume, } 1 \text { vol\% }=10,000 \mathrm{ppmv} \\ \text { VSS } & \text { vapor sampling system } \\ \text { WHC } & \text { Westinghouse Hanford Company }\end{array}$

\section{Acknowledgements}

The author wishes to thank Chris Simonen for her work verifying data and generating tables, and Shas Mattigod for his help with the construction and reviews of this document. 


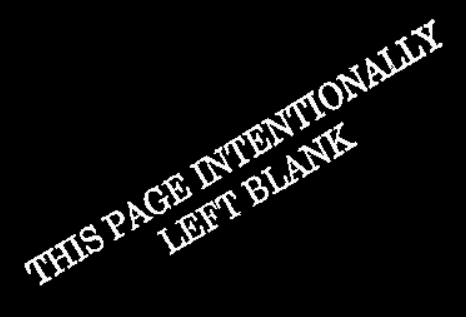


WHC-SD-WM-ER-439 REV. 1

Tank 241,-BX-104 Headspace Gas and Vapor Characterization Results

for Samples Collected in December 1994

\subsection{INTRODUCTION}

\subsection{Characterization Objectives}

Tank BX-104 headspace gas and vapor samples were collected and analyzed to help determine the potential risks of fugitive emissions to tank farm workers. The drivers and objectives of waste tank headspace sampling and analysis are discussed in Program.Plan for the Resolution of Tank Vapor Issues (Osborne and Huckaby 1994). Tank BX-104 was vapor sampled in accordance with Data Quality Objectives for Generic In-Tank Health and Safety Issue Resolution (Osborne et al. 1994).

\subsection{Characterization Data Criteria}

Data Quality Objectives for Generic In-Tank Health and Safety Issue Resolution describes parameters for data collection to ensure appropriate conclusions can be drawn from the data. Tank headspace characterization data were collected to help in the evaluation of 1) headspace flammability, and 2) identification and quantification of compounds of toxicological concern.

Single Shell Tank Interim Operational Safety Requirements (Dougherty 1995) specifies that combustible constituents in tank headspaces be maintained below $25 \%$ of the lower flammability limit (LFL). This essentially agrees with National Fire Protection Association requirements that combustible concentrations be maintained at or below $25 \%$ of the LFL (NFPA 1992). However, current governing operating specifications for single shell waste tanks, such as tank BX-104, specify that combustible constituents be maintained at or below $20 \%$ of the LFL (Boyles 1994).

Headspace characterization data are used by Westinghouse Hanford Company (WHC) Tank Waste Remediation Systems Industrial Hygiene as source term data in the industrial hygiene strategy to protect workers from tank fugitive emissions. Because selection of worker protective equipment must be based on industrial hygiene monitoring of the work place and not on source term data (29 CFR 1910.120), tank headspace characterization data can not be used for this purpose. Furthermore, because there are mechanisms by which headspace constituents can be either diluted or concentrated as they are released to the atmosphere, the headspace characterization data should not be considered to be representative of emissions at the point of emission.

These statements notwithstanding, the data quality objectives document specifies that the industrial hygiene group be advised if constituents with toxicological properties exceed $50 \%$ of the appropriate consensus exposure standard (CES) for non-carcinogens, or $10 \%$ of the appropriate CES for carcinogens. A CES is defined as the most stringent of known regulatory or recommended toxicological values for the workplace (Osborne et al. 1994).

\subsection{Sampling Overview}

Tank BX-104 headspace characterization data presented here are from a single sampling event. Samples collected are thought to have been representative of the tank headspace when the tank was sampled (Meacham et al. 1995), and sample analyses were designed to provide a reasonably accurate and 


\section{WHC-SD-WM-ER-439 REV. 1}

complete characterization of the significant headspace constituents. No assessment has been made of how the tank BX-104 headspace composition changes with time, though studies of tank C-103 suggest that composition changes probably occur very slowly in passively ventilated tanks, such as tank BX-104 (Huckaby and Story 1994).

\subsection{Tank Headspace Dynamics}

Tank BX-104 is the first tank in a 3-tank cascade with tanks BX-105 and BX-106. It is connected to tank BX-105 via a 7.4-cm (2.9-in.) inside diameter, 7.6-m (25-ft) long cascade line. Tanks BX-105 and BX-106 are connected by a similar line. Since these cascade lines connect the headspaces of these tanks, gases and vapors originating from the wastes in tank BX-105 or tank BX-106 may be transferred to tank BX-104 (unless the cascade lines are obstructed). At this time, however, no headspace characterization data are available for either tanks BX-105 or BX-106 to assess their potential effect on tank BX-104.

The cascade of tanks BX-104, BX-105, and BX-106 is passively ventilated, which means that the tanks are allowed to exhale air, waste gases, and vapors as the barometric pressure falls, and inhale ambient air as the barometric pressure rises. Each of these tanks has its own filtered breather riser. Barometric pressure typically rises and falls on a diurnal cycle, producing an average daily exchange of air equal to about $0.46 \%$ of each tank headspace (Huckaby 1994). Changes in the concentrations of tank headspace constituents due to barometric pressure changes are consequently very slow. 


\subsection{SAMPLING EVENT}

Headspace gas and vapor samples were collected from tank BX-104 using the vapor sampling system (VSS) on December 30, 1994 by WHC Sampling and Mobile Laboratories (WHC 1995). Sample collection and analysis were performed as directed by Tank 241-BX-104 Tank Characterization Plan (the TCP), (Carpenter 1994). The tank headspace temperature was determined to be $22.8^{\circ} \mathrm{C}$. Air from the BX-104 headspace was withdrawn from a single elevation via a $8.5-\mathrm{m}$ long heated sampling probe mounted in riser 1 , and transferred via heated tubing to the VSS sampling manifold. All heated zones of the VSS were maintained at approximately $60^{\circ} \mathrm{C}$. All tank air samples were collected between 11:10 a.m. and 2:15 p.m., with no anomalies noted.

Sampling media were prepared and analyzed by WHC, Oak Ridge National Laboratories (ORNL), and Pacific Northwest Laboratories (PNL). The 40 tank air samples and 2 ambient air control samples collected are listed in Table $2-1$ by analytical laboratory. Table 2-1 also lists the 14 trip blanks and 2 field blanks provided by the laboratories.

A general description of vapor sampling and sample anaiysis methods is given by Huckaby and Babad (1995). The sampling equipment, sample collection sequence, sorbent trap sample air flow rates and flow times, chain of custody information, and a discussion of the sampling event itself are given in WHC (1995). 


\subsection{INORGANIC GASES AND VAPORS}

Analytical results of sorbent trap and SUMMA ${ }^{\mathrm{TM}, 1}$ canister tank air samples for selected inorganic gases and vapors are given in Table 3-1 in parts per million by volume (ppmv) in dry air. The concentration of water vapor given in Table 3-1 has been adjusted to tank conditions and are given in Section 3.3. Inorganic analyte sorbent traps and SUMMA ${ }^{\text {TM }}$ canisters were prepared and analyzed by PNL (Pool et al. 1995). PNL analyses of SUMMA ${ }^{T M}$ canisters and sorbent traps for inorganic compounds were performed 54 and 12 days respectively, after sample collection (Ligotke 1995), which were within the 60-day holding time requirement of the WHC quality assurance project plan (Keller 1994). PNL results were produced at PNL quality assurance impact level 2.

\subsection{Ammonia, Hydrogen, and Nitrous Oxide}

The ammonia concentration in the headspace of tank BX-104 was reported as 235 ppmv. Ammonia has been observed in virtually all of the passively ventilated waste tanks sampled to date, at concentrations ranging from about 3 ppmv in tank C-108 (Lucke et al. 1995), to 1040 ppmv in BY-108 (McVeety et al. 1995). Given the LFL of ammonia in air is about 15 by volume (vol\%), the measured $235 \mathrm{ppmv}$ corresponds to about $0.16 \%$ of the LFL, and does not contribute appreciably to the flammability of the headspace.

The concentration of hydrogen in tank BX-104 was determined to be $<94$ ppmv. Hydrogen in the waste tanks is of concern as a fuel. Given that the LFL for hydrogen in air is about $4 \mathrm{vol} \%, 94 \mathrm{ppmv}$ hydrogen concentration in tank BX-104 corresponds to about $0.24 \%$ of its LFL. At this level, hydrogen is not a flammability concern in tank BX-104.

The nitrous oxide concentration in tank BX-104 headspace was measured at 143 ppmv. Nitrous oxide has been detected in other passively ventilated waste tanks at concentrations as low as about 12 ppmv in tank TX-105 (Klinger et al. 1995), and as high as about 878 ppmv in U-103 (Ligotke et al. 1995). Under the proper conditions, nitrous oxide can serve as an oxidizer to support combustion. However, Cashdollar et al. (1992) found that nitrous oxide had no significant effect on the flammability of hydrogen and air mixtures for hydrogen concentrations less than 20 vol\%, and that "small amounts of nitrous oxide (relative to air) do not appear to have much effect on the flammability". Their results suggest the measured nitrous oxide concentration is much too low to have a significant effect on the flammability of the tank BX-104 headspace.

\subsection{Carbon Monoxide and Carbon Dioxide}

The concentration of carbon monoxide in the tank $\mathrm{BX}-104$ headspace was reported as $<12 \mathrm{ppmv}$. In ambient air it typically ranges from 0.05 to $0.15 \mathrm{ppmv}$. Because different analytical methods have been used to measure carbon monoxide in the waste tanks sampled to date, the information on carbon monoxide has varied from tank to tank. However, elevated waste tank headspace carbon monoxide concentrations are common, and are thought to be due to the decomposition of organic waste in the tanks.

The average carbon dioxide concentration in the tank BX-104 headspace, $74 \mathrm{ppmv}$, is significantly lower than it is in ambient air. Carbon dioxide is normally present in the ambient air at a concentration of 350 to $400 \mathrm{ppmv}$, and is typically lower than ambient in the waste tank headspaces. Carbon dioxide introduced by air exchange with the atmosphere is readily absorbed by caustic supernatant and interstitial liquids of the

1 SUMMA is a trademark of Molectrics, Inc., Cleveland, Ohio. 
waste tanks, and converted to carbonate in solution. The $74 \mathrm{ppmv}$ of carbon dioxide measured in tank BX104 is typical for the waste tanks sampled to date.

\subsection{Nitric Oxide, Nitrogen Dioxide, Water and Tritium}

Nitric oxide and nitrogen dioxide concentrations in the tank BX-104 headspace were determined to be 0.3 ppmv and $\leq \mathbf{0 . 0 3}$ ppmv, respectively. These are both acid gases that would have very low equilibrium concentrations above the high pH sludge in tank BX-104. The measurable presence of nitric oxide may be due to its formation from oxygen and nitrogen in the radiation field of the headspace. These constituents could potentially serve as oxidizers to support combustion, but at the measured concentrations would have a negligible effect on the flammability of the tank BX-104 headspace.

The water vapor concentration of tank BX-104 was determined to be about $5.9 \mathrm{mg} / \mathrm{L}$, at the measured tank headspace temperature of $22.8^{\circ} \mathrm{C}$ and pressure of 1006 mbar ( 754.6 torr), (WHC 1995). This corresponds to a water vapor partial pressure of $8.1 \mathrm{mbar}\left(6.1\right.$ torr), to a dew point of $4.0^{\circ} \mathrm{C}$, and to a relative humidity of $29 \%$.

Silica gel sorbent traps were used to test for tritium. It is assumed that tritium produced by the waste combines with hydroxide ions to form tritium-substituted water. Evaporation of the tritium-substituted water would then result in airborne radioactive contamination. Silica gel sorbent traps adsorb virtually all (normal and tritium-substituted) water vapor from the sampled tank air, and are analyzed at the WHC 222-S laboratory. Radiochemical analysis of the silica gel trap indicated the total activity of the headspace to be less than $50 \mathrm{pCi} / \mathrm{L}$ (WHC 1995).

\subsection{Discussion of Inorganic Gases and Vapors}

Aside from water and carbon dioxide, the most abundant waste constituents in the tank BX-104 headspace are ammonia and nitrous oxide. These have been detected in most tank headspaces sampled to date, and along with hydrogen, are usually the dominate waste species. The concentrations of these vapors in tank BX-104 are typical of other passively ventilated tanks that have been sampled.

The relative standard deviations of the inorganic gas and vapor results given in the last column in Table 3-1 are generally good for the methods and at the measured concentrations. Relative standard deviations range from about $1 \%$ for ammonia to $36 \%$ for carbon dioxide results. Because the precision reported depends both on sampling parameters (e.g., sample flow rate and flow time for sorbent traps) and analytical parameters (e.g., sample preparation, dilutions, etc.), small relative standard deviations suggest proper control was maintained both in the field and in the laboratories. 


\subsection{ORGANIC VAPORS}

Organic vapors in the tank BX-104 headspace were sampled using SUMMA ${ }^{T M}$ canisters, which were analyzed by PNL, and triple sorbent traps (TSTs), which were analyzed by ORNL. Both PNL. and ORNL used a gas chromatograph (GC) equipped with a mass spectrometer (MS) to separate, identify, and quantitate the analytes. Descriptions of sample device cleaning, sample preparations, and analyses are given by Jenkins et al. (1995a) and Pool et al. (1995).

SUMMA ${ }^{\mathrm{TM}}$ sample results should be considered to be the primary organic vapor data for tank BX-104. PNL results were produced at PNL quality assurance impact level 2. All PNL analyses were completed 20 days after sample collection. No holding time study has been performed to determine the stability of analytes in SUMMA ${ }^{\text {Th }}$ canisters in the chemical matrix of the tank samples.

ORNL analyses of TST samples from this and other waste tanks generally agree with, support, and augment the SUMMA ${ }^{T M}$ sample results. However, because certain WHC quality assurance requirements were not satisfied by ORNL, the quality assurance assessment of ORNL. by Hendrickson (1995) should be reviewed before results unique to the TST samples are used for decision making.

All TSTs prepared by ORNL had 3 surrogate compounds added to evaluate sample matrix effects, potential handling, storage, and shipment problems, and analytical instrumentation performance (Jenkins et al. 1995a). ORNL evaluated the surrogate recoveries using a statistical approach similar to that prescribed by SW 846 Method $8260 A$ Volatile Organic Compounds by Gas ChromatographyMass Spectrometry (GCMS) Capillary Column Technique (EPA 1992). Using this approach, ORNL reported that all surrogates had standard deviation values within the $95 \%$ confidence interval for variance, indicating that no bias was introduced in the measurement of analyte quantities (Jenkins 1995a).

\subsection{Positively Identified Organic Compounds}

Positive identification of organic analytes using the methods employed by PNL and ORNL involves matching the GC retention times and MS data from a sample with that obtained when known compounds were analyzed. The concentration of an analyte in the sample is said to be quantitatively measured if the. response of the GCMS has been established at several known concentrations of that analyte (i.e., the GCMS has been calibrated for that analyte), and the MS response to the analyte in the sample is between the lowest and highest responses to the known concentrations (i.e., the analyte is within the calibration range).

ORNL and PNL were assigned different lists of organic compounds, or target analytes, to positively identify and measure quantitatively. The ORNL target analyte list was derived from a review of the tank C-103 headspace constituents by a panel of toxicology experts (Mahlum et al. 1994). The PNL target analyte list included the 40 compounds in the Environmental Protection Agency (EPA) task order 14 (TO-14) method, which are primarily halocarbons and common industrial solvents (EPA 1988), plus 14 analytes selected mainly from the toxicology panel's review of tank C-103.

Table 4-1 lists the organic compounds positively identified and quantitated in SUMMA ${ }^{\mathrm{TM}}$ samples. SUMMA ${ }^{\text {TM }}$ analyses were performed according to the TO-14 methodology, except for methane analysis, which was analyzed with the inorganic gases (Pool et al. 1995). Only 3 of the 40 TO-14 target analytes (trichlorofluoromethane, benzene, and toluen) and 10 of the 14 additional target analytes were measured to be above the 0.005 ppmv detection limit of the analyses. Averages reported are from analyses of 3 SUMMA ${ }^{\text {TM }}$ canister samples. 
Jenkins et al. (1995a) report the positive identification of 23 of 27 target analytes in TST samples. 1,1Dichloroethene, dichloromethane, dibutyl butylphosphonate, and tributyl phosphate were the only TST target analytes not detected. The average concentrations of the 12 positively identified and quantitatated target analytes, from the analysis of 3 TSTs, are given in Table 4-2. Table 4-3 lists 8 compounds for which were outside the instrumental calibration range in at least 1 TST sample, and were consequently not quantitated. Table 4-3 lists the 3 compounds which exceeded their ORNL practical holding times. Tables 4-2, 4-3, and 4-4 are mutually exclusive, so that no analyte appears in more than 1 of these tables.

The ORNL practical holding time is defined as the holding time for which there is a $15 \%$ risk that the concentration of an analyte in the sample will be below its initial concentration. As indicated in Table 4-4, of butanal, 1-butanol, and 2-pentanone exceeded their practical holding times, and may have been affected by the 38 day period between sample collection and analysis (Jenkins 1995b). Jenkins et al (1995b) describe the ORNL practical holding time study, and report practical holding times of butanal, 1-butanol, and 2-pentanone are 1, 17, and 34 days, respectively. It should be noted that the contractual holding time for the TST samples was 60 days.

Eleven target analytes were common to both TST and SUMMATM analyses. Table 4-5 lists these, and their reported average concentrations in TST and SUMMA ${ }^{T M}$ samples. As indicated in Table 4-5, the reported concentrations of ethanenitrile, propanenitrile, $n$-butanenitrile, benzene, toluene, $n$-hexane, and $n$-decane are each significantly higher in TST samples than in SUMMA ${ }^{\text {TM }}$ samples.

The most abundant analytes in Tables 4-1 through 4-4 are 1-butanol, n-tridecane, propanone, and ndodecane, each of which was measured to be above 1 ppmv. At the reported concentrations, the target analytes do not individually or collectively represent a flammability hazard.

\subsection{Tentatively Identified Organic Compounds}

In addition to the target analytes, the ORNL and PNL analytical procedures allow the tentative identification of other organic compounds. Tentative identification of analytes was performed by comparing the MS molecular fragmentation patterns with a library of known MS fragmentation patterns. This method allows an organic analyte to be identified (with reasonable certainty) as an alkane, a ketone, an aldehyde, etc., and may also determine its molecular weight. The method usually does not, however, allow the unambiguous identification of structural isomers, and this ambiguity increases with analyte molecular weight. Many analytes can be tentatively identified with reasonable confidence without having to inject each into the GC/MS to determine their GC retention times or specific MS patterns.

By the nature of the sampling devices, virtually all organic vapors present in the tank headspace are collected by both TST and SUMMA ${ }^{\text {TM }}$ samples. Analyses of the samples are designed to recover, separate, and identify the organic vapors in the samples. TSTs are not good for collecting highly volatile compounds (i.e., molecules more volatile than propane), but are quite good for most others. In contrast, the recovery of very low volatility compounds (e.g., molecules with more than about 15 carbon atoms) and some polar compounds with moderate volatility (e.g., butanal) from SUMMA ${ }^{\mathrm{TM}}$ samples has been problematic.

The list of tentatively identified compounds recovered from SUMMA ${ }^{T M}$ samples, with estimated concentrations, is given in Table 4-6. Compounds are listed in Table 4-6 in the order by which they eluted chromatographically, and only non-zero results are included in the reported averages. Because the list of tentatively identified organic compounds in SUMMA ${ }^{\mathrm{TM}}$ samples is rather long and locating any given compound may be difficult, these compounds have been sorted alphanumerically by compound name in Table 4-7, and also in order of decreasing estimated concentrations in Table 4-8. Numbers in the first 
WHC-SD-WM-ER-439 REV. 1

columns of Tables 4-7 and 4-8 (Cmpd \#) identify the location of the compounds in Table 4-6. Estimated concentrations are in $\mathrm{mg} / \mathrm{m}^{3}$, based on dry air at $0^{\circ} \mathrm{C}$ and 1.01 bar.

The list of tentatively identified compounds detected in TST samples and their estimated concentrations is given in Table 4-9. Compounds are listed in Table 4-9 according to the order by which the eluted chromatographically. The averages reported by ORNL in Table 4-9 are all 3-sample averages, and if an analyte was not detected in a sample, its concentration in that sample was considered to be zero for averaging purposes.

Estimated concentrations are in $\mathrm{mg} / \mathrm{m}^{3}$, based on dry air at $0^{\circ} \mathrm{C}$ and $1.01 \mathrm{bar}$.

As with the SUMMATM results, the list of compounds tentatively identified in TSTs has been sorted alphanumerically in Table 4-10, and also in order of decreasing estimated concentrations in Table 4-11. Numbers in the first columns of Tables 4-10 and 4-11 (Cmpd \#) identify the location of the compounds in Table 4-9.

The ORNL and PNL methods used to tentatively identify and estimate concentrations are described by Jenkins et al. (1995a) and Pool et al. (1995), respectively, and should be reviewed before this data are used for decision making. The quantitative measurement of all observed analytes is outside the scope and budget of these analyses, and the estimation of concentrations involves several important assumptions. The validity of each assumption depends on the analyte, and such factors as the specific configuration of the analytical instrumentation.

Concentrations given in Tables 4-6 and 4-9 should be considered rough estimates. Results in Tables 4-6 and 4-9 are presented in terms of observed chromatographic peaks, and are not adjusted for the occurrence of split peaks or the assignment of the same identizy to different peaks (e.g., Cmpd \# 34 and 55 in Table 4-9). In these instances, the estimated concentration of a compound appearing in more than 1 peak is simply the sum of the individual peak estimates.

\subsection{Discussion of Organic Compounds}

A convenient way to consider the organic compounds listed in Tables 4-1 through 4-9 is to separate them into 2 categories: 1) Organic compounds added to tank BX-104 as waste that are still evaporating; and 2) organic compounds that have been generated by reactions of the original waste.

The first category encompasses all organic compounds that were placed into the tank as waste. It includes the tentatively identified alkyl-substituted decahydronaphthalenes, and semivolatile branched and straightchain alkanes, which were used as diluents of tributyl phosphate in various piutonium extraction processes. The semivolatile straight-chain alkanes (i.e., n-undecane, n-dodecane, n-tridecane, n-tetradecane, and npentadecane) are often referred to in Hanford site literature as the normal paraffinic hydrocarbons (NPHs).

The tentatively identified cyclosiloxanes (i.e., Cmpd \# 9 and 16 in Table 4-9) may also be in this category. Small quantities of siloxanes may have been introduced to the waste tank through their use as process surfactants, but they may also be present in the headspace due to their use in liquid traps at the tank's breather riser.

The second category includes all organic compourids that have been generated via radiolytic and chemical reactions of the waste. The majority of compounds listed in Tables 4-1 through 4-11 fall into this category, including the alcohols, aldehydes, ketones, nitriles, alkenes, alkyl nitrates, and volatile alkanes, all of which have been associated with the degradation of the NPHs. While both larger and smaller molecules are 
generated from the waste, the most abundant of these in the headspace are the smaller, short-chain volatile compounds.

The notable absence of tributyl phosphate in the tank BX-104 samples may be due to a sampling difficulty. The abundance of the tributyl phosphate difuents and their degradation products is reason to expect tributyl phosphate to be present in the tank waste. 1-Butanol, which had the highest reported concentration of compounds in TST samples and the third highest concentration of organic compounds in SUMMA ${ }^{\text {TM }}$ samples, is known to be a product of the hydrolysis of tributyl phosphate. Furthermore, informal tests by ORNL indicate that tributyl phosphate is adsorbed by the glass fiber filters used during sampling to protect the samples from radiolytic particulate contamination. Based on these considerations, the concentration of tributyl phosphate in the tank BX-104 headspace should be considered to be unknown.

The total organic vapor concentration of tank BX-104 was estimated by Jenkins et al.(1995a) to be about $100 \mathrm{mg} / \mathrm{m}^{3}$ from the analysis of a single TST sample by GC with flame ionization detection. A summation of concentrations of positively and tentatively identified compounds in 3 TST samples by GCMS indicated the total organic vapor concentration to be about $85 \mathrm{mg} / \mathrm{m}^{3}$.

Jenkins et al. (1995a) reported that propanone, $n$-dodecane, and $n$-tridecane were detected in the trip and field TST blanks at trace levels. The concentrations of these analytes in the TST blanks were less than 1 $\%$ of their concentrations in tank BX-104 samples. Dichloromethane was also detected in the TST blanks, but not in the tank BX-104 samples. Jenkins et al (1995a). also report that benzene and toluene were detected in the TST field blanks, at levels less than half of the tank samples.

Ambient air SUMMA ${ }^{T M}$ samples collected during the tank BX-104 sampling event suggest the VSS manifold may have been contaminated with trace amounts of acetone. Specifically, analysis of an ambient air sample collect upwind of the VSS (not through the VSS manifold) indicated acetone to be present at < 0.005 ppmv, while an ambient air sample collected through the VSS (to check system cleanliness) was determined to have about $0.012 \mathrm{ppmv}$ of acetone. Residual amounts of acetone, used as a cleaning solvent, may have been present in the VSS transfer tubing.

In summary, the organic vapor concentrations in tank BX-104 are relatively high. The organic vapors in tank BX-104 clearly indicate the presence of the semivolatile NPHs and their degradation products in the tank waste. Though tributyl phosphate was not detected in any of the headspace samples, there is strong evidence that it is also present in the waste. 


\subsection{SUMMARY}

The tank BX-104 headspace was sampled in December 1994 for gases and vapors to address flammability and industrial hygiene concerns. Results unique to the sampling event and essentially all results have been reported. It was determined that no headspace constituents exceeded the flammability notification limits, but that ammonia, measured to be 235 ppmv, exceeded the $150 \mathrm{ppmv}$ industrial hygiene notification limit specified in the current Vapor Sampling and Analysis Plan (Homi 1995). 
WHC-SD-WM-ER-439 REV. 1

\subsection{REFERENCES}

29 CFR 1910.120, 1993, "Hazardous Waste Operations and Emergency Response", Code of Federal Regulations.

Boyles, V. C., 1994, Operating Specifications for Single Shell Waste Storage Tanks, OSD-T-151-00013 Rev. D-4, Westinghouse Hanford Company, Richland, Washington.

Burnum, S. T., 1995, Qualification of Reported WHC Vapor Program Data, (letter 95-CHD-065 to president, Westinghouse Hanford Company, August 18), Department of Energy, Richland Operations Office, Richland, Washington.

Carpenter, B. C., 1994, Tank 241-BX-104 Tank Characterization Plan, WHC-SD-WM-TP-296 Rev. 0, Westinghouse Hanford Company, Richland, Washington.

Cashdollar, K. L., M. Hertzberg, I. A. Zlochower, C. E. Lucci, G. M. Green, and R. A. Thomas, 1992, Laboratory Flammability Studies of Mixtures of Hydrogen, Nitrous Oxide, and Air, WHC-SD-WMES-219 Rev. 0, Westinghouse Hanford Company, Richland, Washington.

Dougherty, L. F., 1995, Single Shell Tank Interim Operational Safety Requirements, WHC-SD-WM-OSR005 Rev. 0, Westinghouse Hanford Company, Richland, Washington.

EPA 1988, Compendium of Methods for the Determination of Toxic Organic Compounds in Ambient Air, PB90-127374, U.S. Environmental Protection Agency, Washington, D.C.

EPA 1992, Test Methods for Evaluating Solid Waste, SW-846 Rev. 1, U.S. Environmental Protection Agency, Washington, D.C.

Hendrickson, R. W., 1995, Tank Vapor Characterization Oak Ridge National Laboratories Quality Assurance Assessment, TWRSQA-95-0012, Westinghouse Hanford Company, Richland, Washington.

Homi, C.S., 1995, Vapor Sampling and Analysis Plan, WHC-SD-WM-TP-335 Rev. 0G, Westinghouse Hanford Company, Richland, Washington.

Huckaby, J. L., 1994, Tank 241-C-103 Headspace Flammability, WHC-EP-0734 Rev. 1, Westinghouse Hanford Company, Richland, Washington.

Huckaby, J. L., H. Babad, and D. R. Bratzel, 1995, Headspace Gas and Vapor Characterization Summary for the 43 Vapor Program Suspect Tanks, WHC-SD-WM-ER-514 Rev. 0, Westinghouse Hanford Company, Richland, Washington.

Huckaby, J. L., and M. S. Story, 1994, Vapor Characterization of Tank 241-C-103, WHC-EP-0780 Rev. 0, Westinghouse Hanford Company, Richland, Washington.

Jenkins, R. A., 1995a, Untitled, (Letter 090195A to D. Bratzel, September 1), Oak Ridge National Laboratory, Oak Ridge, Tennessee.

Jenkins, R. A., 1995b, Untitled, (Letter 091495A to D. Bratzel, September 14), Oak Ridge National Laboratory, Oak Ridge, Tennessee. 
Jenkins, R. A, A. B. Dindal, C. Y. Ma, M. A. Palausky, J. T. Skeen, and C. K. Bayne, 1995a, Analysis of Tank 241-BX-104 Headspace Components, ORNL-CASD-FR-241BX104.95 Rev. 0, Oak Ridge National Laboratory, Oak Ridge, Tennessee.

Jenkins, R. A, A. B. Dindal, C. Y. Ma, M. A. Palausky, J. T. Skeen, and C. K. Bayne, 1995b, Analysis of Tank 241-TY-104 Headspace Components, ORNL-CASD-FR-241TY104.95 Rev. 1, Oak Ridge National Laboratory, Oak Ridge, Tennessee.

Keller, K.L., 1994, Quality Assurance Project Plan for Tank Vapor Characterization, WHC-SD-WM-QAPP013 Rev.2, Westinghouse Hanford Company, Richland, Washington.

Klinger, G. S., T. W. Clauss, M. W. Ligotke, K. H. Pool, R. B. Lucke, B. D. MoVeety, O. P. Bredt, J. S. Young, M. McCulloch, J. S. Fruchter, and S. C. Goheen, 1995, Vapor Space Characterization of Waste Tank 241-TX-105: Results from Samples Collected Through the Vapor Sampling System on 12/20/94, PNL-10594 UC-606, Pacific Northwest Laboratory, Richland, Washington.

Ligotke, M.W., 1995, PNL Vapor Project Analytical Holding Times, (Letter to D.R. Bratzel, September 23, 1995), Pacific Northwest Laboratory, Richland, Washington.

Ligotke, M. W., K. H. Pool, T. W. Clauss, B. D. McVeety, G. S. Klinger, K. B. Olsen, O. P. Bredt, J. S. Fruchter, and S. C. Goheen, 1995, Vapor Space Characterization of Waste Tank 241-U-103: Results from Samples Collected on 2/15/95, PNL-10813 UC-606, Pacific Northwest Laboratory, Richland, Washington.

Lucke, R. B., M. W. Ligotke, K. H. Pool, T. W. Clauss, A. K. Sharma, B. D. McVeety, M. McCulloch, J. S. Fruchter, and S. C. Goheen, 1995, Vapor Space Characterization of Waste Tank 241-C-108: Results from Samples Collected Through the Vapor Sampling System on 8/5/94, PNL-10351 UC606, Pacific Northwest Laboratory, Richland, Washington.

Mahlum, D. D., J. Y. Young, and R. E. Weller, 1994, Toxicologic Evaluation of Analytes from Tank 231-C103, PNL-10189, Pacific Northwest Laboratory, Richiand, Washington.

McVeety, B. D., T. W. Clauss, M. W. Ligotke, K. H. Pool, R. B. Lucke, G. S. Klinger, J. S. Young, M. McCulloch, J. S. Fruchter, and S. C. Goheen, 1995, Vapor Space Characterization of Waste Tank 241-BY-108: Results from Samples Collected on 10/27/94, PNL-10495 UC-606, Pacific Northwest Laboratory, Richland, Washington.

Meacham, J.E., H.Babad, R.J. Cash, G.T. Dukelow, S.J. Eberlein, D.W. Hamilton, G.D. Johnson, J.W. Osborne, M.A. Payne, D.J. Sherwood, D.A. Turner, and J.L. Huckaby, 1995, Approach for Tank Safety Characterization of Hanford Site Waste, WHC-EP-0843 Rev.0, UC-2070, Westinghouse Hanford Company, Richland, Washington.

NFPA 1992, Standard on Explosion Prevention Systems, NFPA 69, National Fire Protection Association, Quincy, Massachusetts.

Osborne, J. W., and J. L. Huckaby, 1994, Program Plan for the Resolution of Tank Vapor Issues, WHC-EP0562 Rev. 1, Westinghouse Hanford Company, Richland, Washington.

Osborne, J. W., J. L. Huckaby, T. P. Rudolph, E. R. Hewitt, D. D. Mahlum, J. Y. Young, and C. M. Anderson, 1994, Data Quality Objectives for Generic In-Tank Health and Safety Issue Resolution, WHC-SD-WM-DQO-002, Westinghouse Hanford Company, Richland, Washington. 
WHC-SD-WM-ER-439 REV. 1

Pool, K. H, T. W. Clauss, M. W. Ligotke, R. B. Lucke, B. D. McVeety, G. S. Klinger, K. B. Olsen, M. McCulloch, J. S. Fruchter, and S. C. Goheen, 1995, Vapor Space Characterization of Waste Tank 241-BX-104: Results from Samples Collected on 12/30/94, PNL-10642 UC-606, Pacific Northwest Laboratory, Richland, Washington.

WHC 1995, Vapor and Gas Sampling of Single-Shell Tank 241-BX-104 Using the Vapor Sampling System, WHC-SD-WM-RPT-113, Westinghouse Hanford Company, Richland, Washington. 


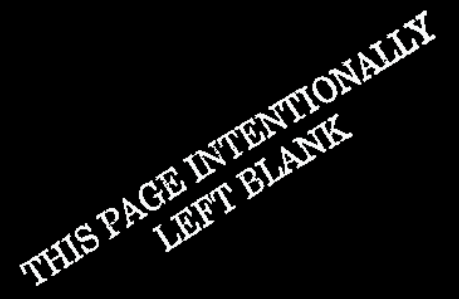


WHC-SD-WM-ER-439 REV. 1

Table 2-1

Tank BX-104 Gas and Vapor Sample Type and Number

\begin{tabular}{|c|c|c|c|c|}
\hline Laboratory & Sampling Device & $\begin{array}{c}\text { Nominal Sample } \\
\text { Volume (L) }\end{array}$ & Target Analytes & Number of Samples \\
\hline $\begin{array}{l}\text { Oak Ridge National } \\
\text { Laboratories }\end{array}$ & Triple Sorbent Trap & $\begin{array}{l}0.2 \\
1.0 \\
4.0\end{array}$ & $\begin{array}{l}\text { Organic vapors } \\
\text { Organic vapors } \\
\text { Organic vapors }\end{array}$ & $\begin{array}{l}4 \text { tank air samples } \\
4 \text { tank air samples } \\
4 \text { tank air samples } \\
+2 \text { trip blanks } \\
+2 \text { field blanks } \\
\end{array}$ \\
\hline \multirow[t]{5}{*}{$\begin{array}{l}\text { Pacific Northwest } \\
\text { Laboratories }\end{array}$} & $\begin{array}{l}\text { Acidified Carbon Sorbent } \\
\text { Trap }\end{array}$ & 3.0 & Ammonia & $\begin{array}{l}6 \text { tank air samples } \\
+3 \text { trip blank }\end{array}$ \\
\hline & $\begin{array}{l}\text { Triethanolamine Sorbent } \\
\text { Trap }\end{array}$ & 3.0 & Nitrogen Dioxide & $\begin{array}{l}6 \text { tank air samples } \\
+3 \text { trip blank }\end{array}$ \\
\hline & $\begin{array}{l}\text { Oxidation Bed }+ \text {. } \\
\text { Triethanolamine Sorbent } \\
\text { Trap }\end{array}$ & 3.0 & Nitric Oxide & $\begin{array}{l}6 \text { tank air samples } \\
+3 \text { trip blank }\end{array}$ \\
\hline & Silica Gel Sorbent Trap & 3.0 & Water vapor & $\begin{array}{l}6 \text { tank air samples } \\
+3 \text { trip blanks }\end{array}$ \\
\hline & SUMMA $^{\mathrm{TM}}$ canister & 6.0 & $\begin{array}{l}\text { Carbon Dioxide, } \\
\text { Carbon Monoxide, } \\
\text { Hydrogen, Methane, } \\
\text { Nitrous Oxide, Organic } \\
\text { vapors }\end{array}$ & $\begin{array}{l}3 \text { tank air samples }+2 \\
\text { ambient air samples }\end{array}$ \\
\hline WHC 222-S Laboratory & Silica Gel Sorbent Trap & 1.0 & $\begin{array}{l}\text { Tritium-Substituted Water } \\
\text { Vapor }\end{array}$ & 1 tank air sample \\
\hline
\end{tabular}




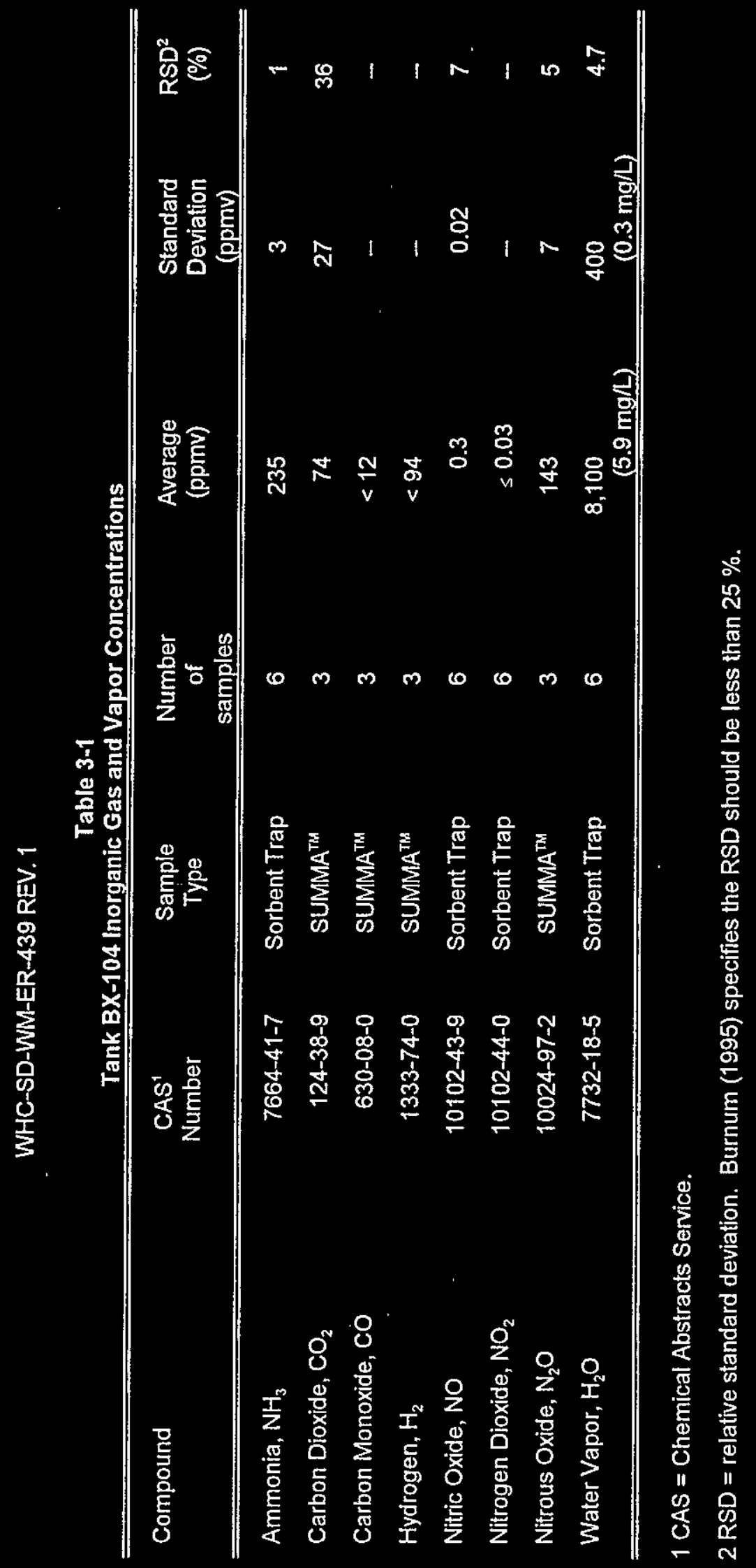


Table 4-1

Tank BX-104 Quantitatively Measured Organic Compounds in SUMMA ${ }^{\text {TM }}$ Samples Analyses by Pacific Northwest Laboratory

\begin{tabular}{clcccc}
\hline \hline $\begin{array}{c}\text { Cmpd } \\
\#\end{array}$ & Compound & $\begin{array}{c}\text { CAS } \\
\text { Number }\end{array}$ & $\begin{array}{c}\text { Average } \\
(\mathrm{ppmV})\end{array}$ & $\begin{array}{c}\text { Standard } \\
\text { Deviation } \\
\text { (ppmv) }\end{array}$ & $\begin{array}{c}\text { RSD }^{3} \\
(\%)\end{array}$ \\
\hline \hline 1 & Propanenitrile (acetonitrile) & $75-05-8$ & 0.052 & - & - \\
2 & Propanone (acetone) & $67-64-1$ & 1.40 & 0.37 & 26 \\
3 & Trichlorofluoromethane & $75-69-4$ & 0.14 & 0.042 & 30 \\
4 & Propanol & $71-23-8$ & 0.32 & 0.098 & 30 \\
5 & 2-Butanone & $78-93-3$ & 0.22 & 0.010 & 4 \\
6 & Tetrahydrofuran & $109-99-9$ & 0.36 & 0.19 & 5 \\
7 & n-Butanenitrile & $109-74-0$ & 0.020 & 0.005 & 24 \\
8 & Benzene & $71-43-2$ & 0.005 & 0.0003 & 6 \\
9 & n-Heptane & $142-82-5$ & 0.067 & 0.001 & 2 \\
10 & 4-Methyl-2-Pentanone & $108-10-1$ & 0.011 & 0.0003 & 3 \\
11 & Pyridine & $110-86-1$ & 0.089 & 0.028 & 31 \\
12 & Toluene & $108-88-3$ & 0.0070 & 0.0002 & 3 \\
13 & n-Decane & $124-18-5$ & 0.012 & - & - \\
14 & Methane & $74-82-8$ & $<61$ & -- & - \\
\hline \hline
\end{tabular}

$1 \mathrm{CAS}=$ Chemical Abstract Service.

2 Average of 3 samples.

3 RSD = relative standard deviation. Burnum (1995) specifies the RSD should be less than $25 \%$.

4 This compound was only detected in 1 sample. 
Table 4-2

Tank BX-104 Quantitatively Measured Organic Compounds in TST Samples Analyses by Oak Ridge National Laboratory ${ }^{\prime}$

\begin{tabular}{clcccc}
\hline $\begin{array}{c}\text { Cmpd } \\
\#\end{array}$ & Compound & $\begin{array}{c}\text { CAS }^{2} \\
\text { Number }\end{array}$ & $\begin{array}{c}\text { Average } \\
\text { (ppmv) }\end{array}$ & $\begin{array}{c}\text { Standard } \\
\text { Deviation } \\
\text { (ppmv) }\end{array}$ & $\begin{array}{c}\text { RSD }^{4} \\
(\%)\end{array}$ \\
\hline 1 & Ethanenitrile (acetonitrile) & $75-05-8$ & 0.34 & 0.02 & 5 \\
2 & Propanenitrile & $107-12-0$ & 0.070 & 0.004 & 5 \\
3 & n-Hexane & $110-54-3$ & 0.16 & 0.02 & 11 \\
4 & n-Butanenitrile & $109-74-0$ & 0.059 & 0.005 & 8 \\
5 & n-Heptane & $142-82-5$ & 0.067 & 0.011 & 17 \\
6 & 2-Hexanone & $591-78-6$ & 0.059 & 0.005 & 8 \\
7 & n-Octane & $111-65-9$ & 0.043 & 0.002 & 5 \\
8 & 2-Heptanone & $110-43-0$ & 0.093 & 0.009 & 10 \\
9 & n-Nonane & $111-84-2$ & 0.039 & 0.003 & 9 \\
10 & 2-Octanone & $111-13-7$ & 0.043 & 0.006 & 13 \\
11 & n-Decane & $124-18-5$ & 0.037 & 0.003 & 7 \\
12 & n-Undecane & $1120-21-4$ & 0.26 & 0.01 & 5 \\
\hline \hline
\end{tabular}

1 Results in this table are quantitative (as defined in Section 4.1).

$2 \mathrm{CAS}=$ Chemical Abstract Service.

3 Average of $3,200 \mathrm{ml}$ TST samples.

4 RSD = relative standard deviation. Burnum (1995) specifies the RSD should be less than $25 \%$. 
WHC-SD-WM-ER-439 REV. 1

Table 4-3

Tank BX-104 Positively Identified Organic Compounds in TST Samples Analyses by Oak Ridge National Laboratory

\begin{tabular}{clcccc}
\hline \hline $\begin{array}{c}\text { Cmpd } \\
\#\end{array}$ & Compound & $\begin{array}{c}\text { CAS } \\
\text { Number }\end{array}$ & $\begin{array}{c}\text { Average } \\
\text { (ppmv) }\end{array}$ & $\begin{array}{c}\text { Standard } \\
\text { Deviation } \\
\text { (ppmv) }\end{array}$ & $\begin{array}{c}\mathrm{RSD}^{4} \\
(\%)\end{array}$ \\
\hline \hline 1 & Propanone (acetone) & $67-64-1$ & 1.22 & 0.07 & 5 \\
2 & Benzene & $71-43-2$ & 0.011 & 0.001 & 5 \\
3 & Toluene & $108-88-3$ & 0.013 & 0.001 & 7 \\
4 & n-Pentanenitrile & $110-59-8$ & 0.023 & 0.002 & 7 \\
5 & n-Hexanenitrile & $628-73-9$ & 0.020 & 0.002 & 11 \\
6 & n-Heptanenitrile & $629-08-3$ & 0.023 & 0.003 & 11 \\
7 & n-Dodecane & $112-40-3$ & 1.12 & 0.14 & 12 \\
8 & n-Tridecane & $629-50-5$ & 2.01 & 0.28 & 14 \\
\hline \hline
\end{tabular}

1 Results in this table are not quantitative (as defined in Section 4.1) because measured values in at least 1 of the samples are outside instrument calibration limits.

$2 \mathrm{CAS}=$ Chemical Abstract Service.

3 Average of $3,200 \mathrm{ml}$ TST samples.

4 RSD = relative standard deviation. Burnum (1995) specifies the RSD should be less than $25 \%$. 
Table 4-4

Tank BX-104 Positively Identified Organic Compounds in TST Samples for which Practical Holding Times were Exceeded -Analyses by Oak Ridge National Laboratory'

\begin{tabular}{clrrrr}
\hline $\begin{array}{c}\text { Cmpd } \\
\#\end{array}$ & Compound & $\begin{array}{c}\text { CAS }^{2} \\
\text { Number }\end{array}$ & $\begin{array}{c}\text { Average }^{3} \\
\text { (ppmv) }\end{array}$ & $\begin{array}{c}\text { Standard } \\
\text { Deviation } \\
\text { (ppmv) }\end{array}$ & $\begin{array}{c}\text { RSD }^{4} \\
\text { (\%) }\end{array}$ \\
\hline \hline 1 & Butanal $^{5}$ & $123-72-8$ & 0.36 & 0.13 & 36 \\
2 & 1-Butanol & $71-36-3$ & 4.62 & 0.41 & 9 \\
3 & 2-Pentanone & $107-87-9$ & 0.12 & 0.01 & 11 \\
\hline \hline
\end{tabular}

1 Practical holding times are defined and discussed in Section 4.1.

$2 \mathrm{CAS}=$ Chemical Abstract Service.

3 Average of $3,200 \mathrm{ml}$ TST samples.

4 RSD = relative standard deviation. Burnum (1995) specifies the RSD should be less than $25 \%$.

5 The concentration of this analyte is quantitatively measured (as defined in Section 4.1).

6 The concentration of this analyte was not quantitatively measured (as defined in Section 4.1), because the measured concentration was outside of the instrumental calibration limits. 
Table 4-5

Tank BX-104 Comparison of Organic Compounds in TST and SUMMA ${ }^{\text {TM }}$ Samples -Analyses by Pacific Northwest Laboratory and Oak Ridge National Laboratory

\begin{tabular}{lcccc}
\hline \hline Compound & $\begin{array}{c}\text { CAS }^{1} \\
\text { Number }\end{array}$ & $\begin{array}{c}\text { TST } \\
\text { Average }^{2} \\
\text { (ppmv) }\end{array}$ & $\begin{array}{c}\text { SUMMA }^{\text {TM }} \\
\text { Average }^{3} \\
\text { (ppmv) }\end{array}$ & $\begin{array}{c}\text { PRD }^{4} \\
\text { (\%) }\end{array}$ \\
\hline \hline 1,1-Dichloroethene (vinylidene chloride) & $75-35-4$ & $<0.012$ & $<0.005$ & - \\
Dichloromethane (methylene chloride) & $75-09-2$ & $<0.027$ & $<0.005$ & - \\
Propanone (acetone) & $67-64-1$ & 1.22 & 1.4 & 137 \\
Ethanenitrile (acetonitrile) & $75-05-8$ & 0.34 & 0.052 & 147 \\
Propanenitrile & $107-12-0$ & 0.070 & $<0.005$ & $>173$ \\
n-Butanenitrile & $109-74-0$ & 0.059 & 0.020 & 99 \\
Benzene & $71-43-2$ & 0.011 & 0.005 & 75 \\
Toluene & $108-88-3$ & 0.013 & 0.0070 & 60 \\
n-Hexane & $110-54-3$ & 0.16 & $<0.005$ & $>188$ \\
n-Heptane & $142-82-5$ & 0.067 & 0.067 & 0 \\
n-Decane & $124-18-5$ & 0.037 & 0.012 & 102 \\
\hline \hline
\end{tabular}

$1 \mathrm{CAS}=$ Chemical Abstract Senvice.

2 Average of $3,200 \mathrm{ml}$ TST samples by ORNL.

3 Average of 3 samples by PNL.

$4 \mathrm{PRD}=$ percent relative difference. Keller (1994) requires the PRD to be less than $20 \%$. 
WHC-SD-WM-ER-439 REV. 1

Table 4-6

Tank BX-104 Tentatively Identified Organic Compounds in SUMMA ${ }^{\mathrm{TM}}$ Samples in Order of Chromatographic Elution Analyses by Pacific Northwest Laboratory

\begin{tabular}{|c|c|c|c|c|}
\hline$\underset{\#}{\text { Cmpd }}$ & Compound & $\begin{array}{c}\text { CAS }^{1} \\
\text { Number }\end{array}$ & $\begin{array}{c}\text { Average }^{2} \\
\left(\mathrm{mg} / \mathrm{m}^{3}\right)\end{array}$ & $\begin{array}{l}\text { Standard } \\
\text { Deviation } \\
\left(\mathrm{mg} / \mathrm{m}^{3}\right)\end{array}$ \\
\hline 1 & Propene & $115-07-1$ & 0.35 & 0.17 \\
\hline 2 & Propane & $74-98-6$ & 0.32 & 0.03 \\
\hline 3 & Methyl nitrite & $624-91-9$ & 0.13 & 0.02 \\
\hline 4 & Cyclopropane & $75-19-4$ & 0.13 & 0.01 \\
\hline 5 & Isobutane & $75-28-5$ & 0.074 & 0.007 \\
\hline 6 & Methanol & $67-56-1$ & 0.40 & 0.04 \\
\hline 7 & 1-Butene & $106-98-9$ & 0.12 & 0.01 \\
\hline 8 & n-Butane & $106-97-8$ & 0.41 & 0.04 \\
\hline 9 & 2-Methylpropene & $115-11-7$ & 0.077 & 0.008 \\
\hline 10 & Ethanol & $64-17-5$ & 0.16 & 0.04 \\
\hline 11 & 1-Pentene ${ }^{4}$ & $109-67-1$ & 0.06 & - \\
\hline 12 & n-Pentane & $109-66-0$ & 0.28 & 0.05 \\
\hline 13 & 2-Methylpentane & $107-83-5$ & 0.24 & 0.01 \\
\hline 14 & Butanal & $123-72-8$ & 0.42 & 0.08 \\
\hline 15 & 2-Butanol & $78-92-2$ & 0.076 & 0.002 \\
\hline 16 & 1-Butanol & $71-36-3$ & 5.76 & 0.79 \\
\hline 17 & 2-Pentanone & $107-87-9$ & 0.29 & 0.02 \\
\hline 18 & Unknown alkylnitrile & & 0.22 & 0.06 \\
\hline 19 & 1-Pentanol & $71-41-0$ & 0.078 & 0.012 \\
\hline 20 & 2,5-Dimethylhexane & $592-13-2$ & 0.076 & 0.002 \\
\hline 21 & 2-Hexanone & $591-78-6$ & 0.15 & 0.002 \\
\hline 22 & Hexanal $^{4}$ & $66-25-1$ & 0.08 & - \\
\hline 23 & Butyl nitrate & $928-45-0$ & 0.29 & 0.01 \\
\hline 24 & 5-Methyl-2-hexanone ${ }^{5}$ & $110-12-3$ & 0.05 & $<0.01$ \\
\hline 25 & 1.-Hexanol & $111-27-3$ & 0.091 & 0.007 \\
\hline 26 & 3-Heptanone & $106-35-4$ & 0.36 & 0.02 \\
\hline 27 & 2-Heptanone & $10-43-0$ & 0.19 & 0.01 \\
\hline
\end{tabular}


WHC-SD-WM-ER-439 REV. 1

\begin{tabular}{|c|c|c|c|c|}
\hline $\begin{array}{c}\text { Cmpd } \\
\#\end{array}$ & Compound & $\begin{array}{l}\text { CAS }^{1} \\
\text { Number }\end{array}$ & $\begin{array}{l}\text { Average }^{2} \\
\left(\mathrm{mg} / \mathrm{m}^{3}\right)\end{array}$ & $\begin{array}{c}\text { Standard } \\
\text { Deviation } \\
\left(\mathrm{mg} / \mathrm{m}^{3}\right) \\
\end{array}$ \\
\hline 28 & n-Butyl ether ${ }^{4}$ & $142-96-1$ & 0.05 & - \\
\hline 29 & 3-Heptanol ${ }^{4}$ & $589-82-2$ & 0.11 & - \\
\hline 30 & n-Nonane & $111-84-2$ & 0.12 & 0.01 \\
\hline 31 & Pentyl nitrate & $1002-16-0$ & 0.054 & 0.006 \\
\hline 32 & 6-Methyl-2-heptanone & $928-68-7$ & 0.35 & 0.03 \\
\hline 33 & Heptanenitrile & $629-08-3$ & 0.065 & 0.008 \\
\hline 34 & 1-Heptanol ${ }^{4}$ & $111-70-6$ & 0.05 & - \\
\hline 35 & 2-Octanone & $111-13-7$ & 0.11 & 0.01 \\
\hline 36 & 2-Ethyl-1-hexanol & $104-76-7$ & 0.066 & 0.023 \\
\hline 37 & 4-Methyldecane & $2847-72-5$ & 0.061 & 0.006 \\
\hline 38 & Unknown alkylnitrate & & 0.12 & 0.01 \\
\hline 39 & Unknown C9 ketone & & 0.094 & 0.012 \\
\hline 40 & Octanenitrile & $124-12-9$ & 0.059 & 0.009 \\
\hline 41 & 2-Nonanone & $21-55-6$ & 0.074 & 0.012 \\
\hline 42 & n-Undecane & $1120-21-4$ & 1.61 & 0.18 \\
\hline 43 & Unknown C12 alkane & & $<0.08$ & -- \\
\hline 44 & 5-Methyiundecane & $1632-70-8$ & 0.068 & 0.005 \\
\hline 45 & Pentyicyclohexane & $4292-92-6$ & 0.056 & 0.005 \\
\hline 46 & 2,5-Dimethyldecane & $17312-50-4$ & 0.17 & 0.06 \\
\hline 47 & 4-Methylundecane & $2980-69-0$ & 0.071 & 0.016 \\
\hline 48 & 2-Methylundecane & $7045-7 \uparrow-8$ & 0.20 & 0.02 \\
\hline 49 & 3-Methylundecane & $1002-43-3$ & 0.12 & 0.01 \\
\hline 50 & 2-Decanone ${ }^{4}$ & $693-54-9$ & 0.06 & - \\
\hline 51 & Unknown alkane & & 0.14 & 0.05 \\
\hline 52 & n-Dodecane & $112-40-3$ & 6.92 & 0.95 \\
\hline 53 & Decahydro-2,6-dimethyinaphthalene & $1618-22-0$ & 0.12 & 0.02 \\
\hline 54 & Unknown C13 alkane & & 1.72 & 0.23 \\
\hline 55 & Unknown $\mathrm{C} 13$ alkane & & 0.20 & 0.02 \\
\hline 56 & Unknown alkyl decahydronaphthalene ${ }^{5}$ & & 0.22 & 0.005 \\
\hline
\end{tabular}


WHC-SD-WM-ER-439 REV, 1

\begin{tabular}{|c|c|c|c|c|}
\hline$\underset{\#}{\text { Cmpd }}$ & Compound & $\begin{array}{c}\text { CAS }^{1} \\
\text { Number }\end{array}$ & $\begin{array}{c}\text { Average }^{2} \\
\left(\mathrm{mg} / \mathrm{m}^{3}\right)\end{array}$ & $\begin{array}{c}\text { Standard } \\
\text { Deviation } \\
\left(\mathrm{mg} / \mathrm{m}^{3}\right)\end{array}$ \\
\hline 57 & Unknown C13 alkene/Cycloalkane & & 1.03 & 0.12 \\
\hline 58 & Unknown C13 alkane & & 0.35 & 0.03 \\
\hline 59 & Unknown C13 alkane & & 0.43 & 0.04 \\
\hline 60 & Unknown C13 alkane & & 0.33 & 0.03 \\
\hline 61 & 7-Methyltridecane & $26730-14-3$ & 2.68 & 0.26 \\
\hline 62 & Unknown C8 cyclohexane & & 0.21 & 0.02 \\
\hline 63 & n-Tridecane & $629-50-5$ & 8.11 & 0.86 \\
\hline 64 & Unknown C8 cyclohexane & & 0.45 & 0.06 \\
\hline 65 & Unknown C14 alkane & & 0.54 & 0.06 \\
\hline 66 & Unknown C13 alkene/Cycloalkane ${ }^{5}$ & & 0.21 & 0.09 \\
\hline 67 & Unknown C7 cyclohexane ${ }^{5}$ & & 0.31 & 0.015 \\
\hline 68 & 2-Methyltridecane & $1560-96-9$ & 0.12 & 0.02 \\
\hline 69 & 3-Methyltridecane ${ }^{4}$ & $6418-41-3$ & 0.09 & - \\
\hline 70 & Unknown C15 alkane & & 0.60 & 0.08 \\
\hline 71 & Unknown C4 decahydronaphthalene ${ }^{5}$ & & 0.19 & 0.005 \\
\hline 72 & $\mathrm{n}$-Tetradecane & $629-59-4$ & 0.75 & 0.15 \\
\hline 73 & Unknown C15 alkene/ Cycloalkane ${ }^{4}$ & & 0.16 & - \\
\hline 74 & Unknown C9 cyclohexane ${ }^{5}$ & & 0.16 & 0.01 \\
\hline \multicolumn{2}{|c|}{ Sum of tentatively identified compounds: } & & 39.99 & \\
\hline
\end{tabular}

$1 \mathrm{CAS}=$ Chemical Abstract Service.

2 Average of 3 samples by PNL, values listed are estimates.

3 When the analyte was detected in only 2 samples, the entry is the relative difference (i.e., their difference divided by 2).

4 Detected in only 1 sample.

5 Detected in only 2 samples. 
WHC-SD-WM-ER-439 REV. 1

Table 4-7

Tank BX-104 Tentatively Identified Organic Compounds in SUMMA ${ }^{\text {TM }}$ Samples

Sorted Alphanumerically -

Analyses by Pacific Northwest Laboratory

\begin{tabular}{|c|c|c|c|c|}
\hline Cmpd & Compound & $\begin{array}{c}\text { CAS }^{1} \\
\text { Number }\end{array}$ & $\begin{array}{c}\text { Average }^{2} \\
\left(\mathrm{mg} / \mathrm{m}^{3}\right)\end{array}$ & $\begin{array}{c}\text { Standard } \\
\text { Deviation } \\
\left(\mathrm{mg} / \mathrm{m}^{3}\right)\end{array}$ \\
\hline 34 & 1-Heptanol ${ }^{3}$ & $111-70-6$ & 0.05 & - \\
\hline 11 & 1-Pentene ${ }^{4}$ & $109-67-1$ & 0.06 & - \\
\hline 16 & 1-Butanol & $71-36-3$ & 5.76 & 0.79 \\
\hline 25 & 1-Hexanol & $111-27-3$ & 0.091 & 0.007 \\
\hline 19 & 1-Pentanol & $71-41-0$ & 0.078 & 0.012 \\
\hline 7 & 1-Butene & $106-98-9$ & 0.12 & 0.01 \\
\hline 48 & 2-Methylundecane & $7045-71-8$ & 0.20 & 0.02 \\
\hline 35 & 2-Octanone & $111-13-7$ & 0.11 & 0.01 \\
\hline 9 & 2-Methyipropene & $115-11-7$ & 0.077 & 0.008 \\
\hline 50 & 2-Decanone & $693-54-9$ & 0.06 & - \\
\hline 27 & 2-Heptanone & $10-43-0$ & 0.19 & 0.01 \\
\hline 36 & 2-Ethyl-1-hexanol & $104-76-7$ & 0.066 & 0.023 \\
\hline 13 & 2-Methylpentane & $107-83-5$ & 0.24 & 0.01 \\
\hline 68 & 2-Methyltridecane & $1560-96-9$ & 0.12 & 0.02 \\
\hline 15 & 2-Butanol & $78-92-2$ & 0.076 & 0.002 \\
\hline 21 & 2-Hexanone & $591-78-6$ & 0.15 & 0.002 \\
\hline 17 & 2-Pentanone & $107-87-9$ & 0.29 & 0.02 \\
\hline 41 & 2-Nonanone & $21-55-6$ & 0.074 & 0.012 \\
\hline 46 & 2,5-Dimethyldecane & $17312-50-4$ & 0.17 & 0.06 \\
\hline 20 & 2,5-Dimethylhexane & $592-13-2$ & 0.076 & 0.002 \\
\hline 49 & 3-Methylundecane & $1002-43-3$ & 0.12 & 0.01 \\
\hline 69 & 3-Methyltridecane & $6418-41-3$ & 0.09 & - \\
\hline 29 & 3-Heptanol ${ }^{4}$ & $589-82-2$ & 0.11 & - \\
\hline 26 & 3-Heptanone & $106-35-4$ & 0.36 & 0.02 \\
\hline 47 & 4-Methylundecane & $2980-69-0$ & 0.071 & 0.016 \\
\hline 37 & 4-Methyldecane & $2847-72-5$ & 0.061 & 0.006 \\
\hline 24 & 5-Methyl-2-hexanone ${ }^{5}$ & $110-12-3$ & 0.05 & $<0.01$ \\
\hline
\end{tabular}


WHC-SD-WM-ER-439 REV. 1

\begin{tabular}{|c|c|c|c|c|}
\hline$\underset{\#}{C \text { Cmpd }}$ & Compound & $\begin{array}{c}\text { CAS }^{1} \\
\text { Number }\end{array}$ & $\begin{array}{c}\text { Average }^{2} \\
\left(\mathrm{mg} / \mathrm{m}^{3}\right)\end{array}$ & $\begin{array}{l}\text { Standard } \\
\text { Deviation } \\
\left(\mathrm{mg} / \mathrm{m}^{3}\right)\end{array}$ \\
\hline 44 & 5-Methylundecane & $1632-70-8$ & 0.068 & 0.005 \\
\hline 32 & 6-Methyl-2-heptanone & $928-68-7$ & 0.35 & 0.03 \\
\hline 61 & 7-Methyltridecane & $26730-14-3$ & 2.68 & 0.26 \\
\hline 14 & Butanal & $123-72-8$ & 0.42 & 0.08 \\
\hline 23 & Butyl nitrate & $928-45-0$ & 0.29 & 0.01 \\
\hline 4 & Cyclopropane & $75-19-4$ & 0.13 & 0.01 \\
\hline 53 & Decahydro-2,6-dimethylnaphthalene & $1618-22-0$ & 0.12 & 0.02 \\
\hline 10 & Ethanol & $64-17-5$ & 0.16 & 0.04 \\
\hline 33 & Heptanenitrile & $629-08-3$ & 0.065 & 0.008 \\
\hline 22 & Hexanal $^{4}$ & $66-25-1$ & 0.08 & -- \\
\hline 5 & Isobutane & $75-28-5$ & 0.074 & 0.007 \\
\hline 6 & Methanol & $67-56-1$ & 0.40 & 0.04 \\
\hline 3 & Methyl nitrite & $624-91-9$ & 0.13 & 0.02 \\
\hline 28 & n-Butyl ether ${ }^{4}$ & $142-96-1$ & 0.05 & - \\
\hline 8 & n-Butane & $106-97-8$ & 0.41 & 0.04 \\
\hline 52 & n-Dodecane & $112-40-3$ & 6.92 & 0.95 \\
\hline 30 & n-Nonane & $111-84-2$ & 0.12 & 0.01 \\
\hline 12 & n-Pentane & $109-66-0$ & 0.28 & 0.05 \\
\hline 72 & n-Tetradecane & $629-59-4$ & 0.75 & 0.15 \\
\hline 63 & n-Tridecane & $629-50-5$ & 8.11 & 0.86 \\
\hline 42 & n-Undecane & $1120-21-4$ & 1.61 & 0.18 \\
\hline 40 & Octanenitrile & $124-12-9$ & 0.059 & 0.009 \\
\hline 31 & Pentyl nitrate & $1002-16-0$ & 0.054 & 0.006 \\
\hline 45 & Pentylcyclohexane & $4292-92-6$ & 0.056 & 0.005 \\
\hline 2 & Propane & $74-98-6$ & 0.32 & 0.03 \\
\hline 1 & Propene & $115-07-1$ & 0.35 & 0.17 \\
\hline 18 & Unknown alkylnitrile & & 0.22 & 0.06 \\
\hline 38 & Unknown alkylnitrate & & 0.12 & 0.01 \\
\hline 39 & Unknown C9 ketone & & 0.094 & 0.012 \\
\hline
\end{tabular}


WHC-SD-WM-ER-439 REV. 1

\begin{tabular}{|c|c|c|c|c|}
\hline$\underset{\#}{\text { Cmpd }}$ & Compound & $\begin{array}{c}\mathrm{CAS}^{1} \\
\text { Number }\end{array}$ & $\begin{array}{c}\text { Average }^{2} \\
\left(\mathrm{mg} / \mathrm{m}^{3}\right)\end{array}$ & $\begin{array}{c}\text { Standard } \\
\text { Deviation } \\
\left(\mathrm{mg} / \mathrm{m}^{3}\right)\end{array}$ \\
\hline 43 & Unknown C12 alkane & & $<0.08$ & - \\
\hline 51 & Unknown alkane & & 0.14 & 0.05 \\
\hline 54 & Unknown C13 alkane & & 1.72 & 0.23 \\
\hline 55 & Unknown C13 alkane & & 0.20 & 0.02 \\
\hline 56 & Unknown alkyl decahydronaphthalene ${ }^{5}$ & & 0.22 & 0.005 \\
\hline 57 & Unknown $\mathrm{C} 13$ alkene/Cycloalkane & & 1.03 & 0.12 \\
\hline 58 & Unknown C13 alkane & & 0.35 & 0.03 \\
\hline 59 & Unknown C13 alkane & & 0.43 & 0.04 \\
\hline 60 & Unknown C13 alkane & & 0.33 & 0.03 \\
\hline 62 & Unknown C8 cyclohexane & & 0.21 & 0.02 \\
\hline 64 & Unknown C8 cyclohexane & & 0.45 & 0.06 \\
\hline 65 & Unknown C14 alkane & & 0.54 & 0.06 \\
\hline 66 & Unknown $\mathrm{C} 13$ alkene/Cycloalkane $^{5}$ & & 0.21 & 0.09 \\
\hline 67 & Unknown C7 cyclohexane ${ }^{5}$ & & 0.31 & 0.015 \\
\hline 70 & Unknown C15 alkane & & 0.60 & 0.08 \\
\hline 71 & Unknown C4 decahydronaphthalene ${ }^{5}$ & & 0.19 & 0.005 \\
\hline 73 & Unknown C15 alkene/Cycloalkane 4 & & 0.16 & - \\
\hline 74 & Unknown C9 cyclohexane ${ }^{5}$ & & 0.16 & 0.01 \\
\hline \multicolumn{3}{|c|}{ Sum of tentatively identified compounds: } & 39.99 & \\
\hline
\end{tabular}

$1 \mathrm{CAS}=$ Chemical Abstract Service.

2 Average of 3 samples by PNL; values listed are estimates.

3 When the analyte was detected in only 2 samples, the entry is the relative difference (i.e., their difference divided by 2 ).

4 Detected in only 1 sample.

5 Deteced in only 2 samples. 
WHC-SD-WM-ER-439 REV. 1

Table 4-8

Tank BX-104 Tentatively Identified Organic Compounds in SUMMA ${ }^{\text {TM }}$ Samples

Sorted by Estimated Concentration Analyses by Pacific Northwest Laboratory

\begin{tabular}{|c|c|c|c|c|}
\hline Cmpd & Compound & $\begin{array}{c}\mathrm{CAS}^{i} \\
\text { Number }\end{array}$ & $\begin{array}{c}\text { Average }^{2} \\
\left(\mathrm{mg} / \mathrm{m}^{3}\right)\end{array}$ & $\begin{array}{c}\text { Standard } \\
\text { Deviation } \\
\left(\mathrm{mg} / \mathrm{m}^{3}\right)\end{array}$ \\
\hline 63 & n-Tridecane & $629-50-5$ & 8.11 & 0.86 \\
\hline 52 & n-Dodecane & $112-40-3$ & 6.92 & 0.95 \\
\hline 16 & 1-Butanol & $71-36-3$ & 5.76 & 0.79 \\
\hline 61 & 7-Methyltridecane & $26730-14-3$ & 2.68 & 0.26 \\
\hline 42 & n-Undecane & $1120-21-4$ & 1.61 & 0.18 \\
\hline 72 & n-Tetradecane & $629-59-4$ & 0.75 & 0.15 \\
\hline 14 & Butanal & $123-72-8$ & 0.42 & 0.08 \\
\hline 8 & n-Butane & $106-97-8$ & 0.41 & 0.04 \\
\hline 6 & Methanol & $67-56-1$ & 0.40 & 0.04 \\
\hline 26 & 3-Heptanone & $106-35-4$ & 0.36 & 0.02 \\
\hline 1 & Propene & $115-07-1$ & 0.35 & 0.17 \\
\hline 32 & 6-Methyl-2-heptanone & $928-68-7$ & 0.35 & 0.03 \\
\hline 2 & Propane & $74-98-6$ & 0.32 & 0.03 \\
\hline 17 & 2-Pentanone & $107-87-9$ & 0.29 & 0.02 \\
\hline 23 & Butyl nitrate & $928-45-0$ & 0.29 & 0.01 \\
\hline 12 & n-Pentane & $109-66-0$ & 0.28 & 0.05 \\
\hline 13 & 2-Methylpentane & $107-83-5$ & 0.24 & 0.01 \\
\hline 54 & Unknown C13 alkane & & 1.72 & 0.23 \\
\hline 48 & 2-Methylundecane & $7045-71-8$ & 0.20 & 0.02 \\
\hline 27 & 2-Heptanone & $10-43-0$ & 0.10 & 0.01 \\
\hline 46 & 2,5-Dimethyldecane & $17312-50-4$ & 0.17 & 0.06 \\
\hline 10 & Ethanol & $64-17-5$ & 0.16 & 0.04 \\
\hline 21 & 2-Hexanone & $591-78-6$ & 0.15 & 0.002 \\
\hline 3 & Methyl nitrite & $624-91-9$ & 0.13 & 0.02 \\
\hline 4 & Cyclopropane & $75-19-4$ & 0.13 & 0.01 \\
\hline 7 & 1-Butene & $106-98-9$ & 0.12 & 0.01 \\
\hline 68 & 2-Methyltridecane & $1560-96-9$ & 0.12 & 0.02 \\
\hline
\end{tabular}


WHC-SD-WM-ER-439 REV. 1

\begin{tabular}{|c|c|c|c|c|}
\hline$\underset{\#}{C \text { Cmpd }}$ & Compound & $\begin{array}{c}\text { CAS }^{1} \\
\text { Number }\end{array}$ & $\begin{array}{c}\text { Average }^{2} \\
\left(\mathrm{mg} / \mathrm{m}^{3}\right)\end{array}$ & $\begin{array}{c}\text { Standard } \\
\text { Deviation }{ }^{3} \\
\left(\mathrm{mg} / \mathrm{m}^{3}\right)\end{array}$ \\
\hline 49 & 3-Methylundecane & $1002-43-3$ & 0.12 & 0.01 \\
\hline 57 & Unknown C13 alkene/Cycloalkane & & 1.03 & 0.12 \\
\hline 53 & Decahydro-2,6-dimethylnaphthalene & $1618-22-0$ & 0.12 & 0.02 \\
\hline 30 & n-Nonane & $111-84-2$ & 0.12 & 0.01 \\
\hline 29 & 3-Heptanol ${ }^{4}$ & $589-82-2$ & 0.11 & - \\
\hline 35 & 2-Octanone & $111-13-7$ & 0.11 & 0.01 \\
\hline 25 & 1.Hexanol & $111-27-3$ & 0.091 & 0.007 \\
\hline 66 & Unknown C 13 alkene/Cycloalkane ${ }^{5}$ & & 0.21 & 0.09 \\
\hline 69 & 3-Methyltridecane ${ }^{4}$ & $6418-41-3$ & 0.09 & - \\
\hline 22 & Hexanal ${ }^{4}$ & $66-25-1$ & 0.08 & - \\
\hline 70 & Unknown C15 alkane & & 0.60 & 0.08 \\
\hline 19 & 1-Pentanol & $71-41-0$ & 0.078 & 0.012 \\
\hline 9 & 2-Methylpropene & $115-11-7$ & 0.077 & 0.008 \\
\hline 20 & 2,5-Dimethylhexane & $592-13-2$ & 0.076 & 0.002 \\
\hline 15 & 2-Butanol & $78-92-2$ & 0.076 & 0.002 \\
\hline 41 & 2-Nonanone & $21-55-6$ & 0.074 & 0.012 \\
\hline 5 & Isobutane & $75-28-5$ & 0.074 & 0.007 \\
\hline 47 & 4-Methylundecane & $2980-69-0$ & 0.071 & 0.016 \\
\hline 44 & 5-Methylundecane & $1632-70-8$ & 0.068 & 0.005 \\
\hline 36 & 2-Ethyl-1-hexanol & $104-76-7$ & 0.066 & 0.023 \\
\hline 33 & Heptanenitrile & $629-08-3$ & 0.065 & 0.008 \\
\hline 37 & 4-Methyldecane & $2847-72-5$ & 0.061 & 0.006 \\
\hline 50 & 2-Decanone ${ }^{4}$ & $693-54-9$ & 0.06 & - \\
\hline 65 & Unknown C14 alkane & & 0.54 & 0.06 \\
\hline 64 & Unknown C8 cyclohexane & & 0.45 & 0.06 \\
\hline 11 & 1-Pentene ${ }^{4}$ & $109-67-1$ & 0.06 & - \\
\hline 18 & Unknown alkylnitrile & & 0.22 & 0.06 \\
\hline 40 & Octanenitrile & $124-12-9$ & 0.059 & 0.009 \\
\hline 45 & Pentylcyclohexane & $4292-92-6$ & 0.056 & 0.005 \\
\hline
\end{tabular}


WHC-SD-WM-ER-439 REV. 1

\begin{tabular}{|c|c|c|c|c|}
\hline Cmpd & Compound & $\begin{array}{l}\text { CAS }^{1} \\
\text { Number }\end{array}$ & $\begin{array}{l}\text { Average }^{2} \\
\left(\mathrm{mg} / \mathrm{m}^{3}\right)\end{array}$ & $\begin{array}{c}\text { Standard } \\
\text { Deviation } \\
\left(\mathrm{mg} / \mathrm{m}^{3}\right) \\
\end{array}$ \\
\hline 31 & Pentyl nitrate & $1002-16-0$ & 0.054 & 0.006 \\
\hline 51 & Unknown alkane & & 0.14 & 0.05 \\
\hline 24 & 5-Methyl-2-hexanone ${ }^{5}$ & $110-12-3$ & 0.05 & $<0.01$ \\
\hline 28 & n-Butyl ether ${ }^{4}$ & $142-96-1$ & 0.05 & - \\
\hline 34 & 1-Heptanol ${ }^{4}$ & $111-70-6$ & 0.05 & - \\
\hline 59 & Unknown C13 alkane & & 0.43 & 0.04 \\
\hline 58 & Unknown C13 alkane & & 0.35 & 0.03 \\
\hline 60 & Unknown C13 alkane & & 0.33 & 0.03 \\
\hline 55 & Unknown C13 alkane & & 0.20 & 0.02 \\
\hline 62 & Unknown C8 cyclohexane & & 0.21 & 0.02 \\
\hline 67 & Unknown C7 cyclohexane ${ }^{5}$ & & 0.31 & 0.015 \\
\hline 39 & Unknown C9 ketone & . & 0.094 & 0.012 \\
\hline 74 & Unknown C9 cyclohexane ${ }^{5}$ & & 0.16 & 0.01 \\
\hline 38 & Unknown alkylnitrate & - & 0.12 & 0.01 \\
\hline 56 & Unknown alkyi decahydronaphthalene ${ }^{5}$ & & 0.22 & 0.005 \\
\hline 71 & $\begin{array}{l}\text { Unknown C4 decahydro- } \\
\text { naphthalene }\end{array}$ & & 0.19 & 0.005 \\
\hline 43 & Unknown C12 alkane & & $<0.08$ & - \\
\hline 73 & Unknown C15 alkene/Cycloalkane ${ }^{4}$ & & 0.16 & - \\
\hline \multicolumn{3}{|c|}{ Sum of tentatively identified compounds: } & 39.99 & \\
\hline
\end{tabular}

$1 \mathrm{CAS}=$ Chemical Abstract Service.

2 Average of 3 samples by PNL, values listed are estimates.

3 When the analyte was detected in only 2 samples, the entry is the relative difference (i.e., their difference divided by 2 ).

4 Detected in only 1 sample.

5 Detected in only two samples. 
Table 4-9

Tank BX-104 Tentatively Identified Organic Compounds in TST Samples in Order of Chromatographic Elution Analyses by Oak Ridge National Laboratory

\begin{tabular}{|c|c|c|c|c|}
\hline Cmpd & Compound & $\begin{array}{l}\text { CAS' }^{1} \\
\text { Number }\end{array}$ & $\begin{array}{l}\text { Average }^{2} \\
\left(\mathrm{mg} / \mathrm{m}^{3}\right)\end{array}$ & $\begin{array}{c}\text { Standard } \\
\text { Deviation } \\
\left(\mathrm{mg} / \mathrm{m}^{3}\right)\end{array}$ \\
\hline 1 & n-Butane & $106-97-8$ & 0.80 & 0.16 \\
\hline 2 & Ethanol and butane, 2-methyl- & & 0.20 & 0.18 \\
\hline 3 & 1-Propanol & $71-23-8$ & 0.48 & 0.02 \\
\hline 4 & 2-Butanone & $78-93-3$ & 0.26 & 0.01 \\
\hline 5 & Nitrous acid, butyl ester & $544-16-1$ & 0.062 & 0.110 \\
\hline 6 & Furan, tetrahydro- & $109-99-9$ & 0.55 & 0.07 \\
\hline 7 & 1H-Pyrazole, 3-methyi- & $1453-58-3$ & 0.23 & 0.05 \\
\hline 8 & 1-Pentanol & $71-41-0$ & 0.062 & 0.110 \\
\hline 9 & Cyclotrisiloxane, hexamethyl- & $541-05-9$ & 0.48 & 0.16 \\
\hline 10 & Nitric acid, butyl ester & $928-45-0$ & 0.17 & 0.01 \\
\hline 11 & 1-Hexanol & $111-27-3$ & 0.17 & 0.03 \\
\hline 12 & 3-Heptanone & $106-35-4$ & 0.54 & 0.05 \\
\hline 13 & Nitric acid, pentyl ester & $1002-16-0$ & 0.049 & 0.085 \\
\hline 14 & 2-Heptanone, 6-methyl- & $928-68-7$ & 0.59 & 0.08 \\
\hline 15 & 1-Heptanol & $111-70-6$ & 0.052 & 0.090 \\
\hline 16 & Cyclotetrasiloxane, octamethyl- & $556-67-2$ & 0.21 & 0.20 \\
\hline 17 & 1-Hexanol, 2-ethyl- & $104-76-7$ & 0.23 & 0.04 \\
\hline 18 & Oxirane, 2-ethyl-3-propyl-, cis- & $56052-94-9$ & 0.16 & 0.02 \\
\hline 19 & 2-Heptanone, 6-methyl- & $928-68-7$ & 0.15 & 0.02 \\
\hline 20 & 1-Octanol & $111-87-5$ & 0.17 & 0.02 \\
\hline 21 & 2-Nonanone & $821-55-6$ & 0.046 & 0.080 \\
\hline 22 & Octane, 6-ethyl-2-methyl- & $62016-19-7$ & 0.17 & 0.02 \\
\hline 23 & Cyclohexane, pentyl- & $4292-92-6$ & 0.13 & 0.11 \\
\hline 24 & $\begin{array}{l}\text { Naphthalene, decahydro- } \\
\text { 2methyl }\end{array}$ & $2958-76-1$ & 0.037 & 0.064 \\
\hline 25 & Undecane, 6-methyl- & $17302-33-9$ & 0.36 & 0.05 \\
\hline 26 & Undecane, 4-methyl- & $2980-69-0$ & 0.21 & 0.02 \\
\hline
\end{tabular}




\begin{tabular}{|c|c|c|c|c|}
\hline$\underset{\#}{\text { Cmpd }}$ & Compound & $\begin{array}{l}\mathrm{CAS}^{1} \\
\text { Number }\end{array}$ & $\begin{array}{l}\text { Average }{ }^{2} \\
\left(\mathrm{mg} / \mathrm{m}^{3}\right)\end{array}$ & $\begin{array}{l}\text { Standard } \\
\text { Deviation } \\
\left(\mathrm{mg} / \mathrm{m}^{3}\right)\end{array}$ \\
\hline 27 & Undecane, 2-methyl- & $7045-71-8$ & 0.41 & 0.05 \\
\hline 28 & Decane, 3,8-dimethyl- & $17312-55-9$ & 0.30 & 0.04 \\
\hline 29 & Decanè, 2,4,6-trimethyl- & $62108-27-4$ & 0.20 & 0.02 \\
\hline 30 & Cyclohexane, 1-ethyl-4-methyl-, cis- & $4926-78-7$ & 0.57 & 0.06 \\
\hline 31 & Naphthalene, decahydro-2, 6-dimethyl- & $1618-22-0$ & 0.039 & 0.068 \\
\hline 32 & 4-Undecene, 6-methyl & & 0.24 & 0.01 \\
\hline 33 & Undecane, 2,6-dimethyl- & $17301-23-4$ & 2.17 & 0.19 \\
\hline 34 & Dodecane, 3-methyl- & $17312-57-1$ & 0.46 & 0.05 \\
\hline 35 & Decane, 2,3,7-trimethyl- & $62238-13-5$ & 0.16 & 0.02 \\
\hline 36 & Cyclododecane & $294-62-2$ & 0.16 & 0.01 \\
\hline 37 & Naphthaiene, decahydro-2, 3-dimethyl- & $1008-80-6$ & 0.039 & 0.068 \\
\hline 38 & 4-Nonene, 5-butyl- & $7367-38-6$ & 0.085 & 0.074 \\
\hline 39 & Cyclohexane, 2-butyl-1,1,3-trimethyl- & $54676-39-0$ & 0.84 & 0.09 \\
\hline 40 & C6-Cyclohexane & & 1.77 & 0.16 \\
\hline 41 & Undecane, 2,3-dimethyl- & $17312-77-5$ & 0.78 & 0.11 \\
\hline 42 & Decane, 2,3,7-trimethyl- & $62238-13-5$ & 0.85 & 0.11 \\
\hline 43 & Cyclohexane, (2,2-dimethylcyclopentyl)- & $61142-23-2$ & 0.31 & 0.02 \\
\hline 44 & Octane, 2,3,7-trimethyl- & $62016-34-6$ & 3.05 & 0.32 \\
\hline 45 & Cyclohexane, 1,1,3,5-tetramethyl- & $50876-32-9$ & 0.15 & 0.27 \\
\hline 46 & $\begin{array}{l}2(3 \mathrm{H}) \text {-Benzofuranone, } 3 \mathrm{a} \\
4,5,6 \text { - tetrahydro-trimethyl- }\end{array}$ & $16778-26-0$ & 0.30 & 0.03 \\
\hline 47 & 3-Undecanone & $2216-87-7$ & 0.30 & 0.11 \\
\hline 48 & Tridecane, 7-methyl- & $26730-14-3$ & 0.26 & 0.02 \\
\hline 49 & Undecane, 5,5-dimethyl- & $17312-73-1$ & 1.42 & 0.14 \\
\hline 50 & C3-Decahydronaphthalene & & 0.24 & 0.03 \\
\hline 51 & Cyclohexane, 1,3,5-trimethyl-2-octadecyl- & $55282-34-3$ & 0.048 & 0.084 \\
\hline 52 & Dodecane, 2,5-dimethyl- & $56292-65-0$ & 0.061 & 0.100 \\
\hline 53 & C7-Cyclohexane & & 1.07 & 0.07 \\
\hline 54 & Tridecane, 2-methyl- & $1560-96-9$ & 0.48 & 0.04 \\
\hline
\end{tabular}


WHC-SD-WM-ER-439 REV. 1

\begin{tabular}{clrcc}
\hline $\begin{array}{c}\text { Cmpd } \\
\#\end{array}$ & Compound & $\begin{array}{c}\text { CAS }^{1} \\
\text { Number }\end{array}$ & $\begin{array}{c}\text { Average } \\
\left(\mathrm{mg} / \mathrm{m}^{3}\right)\end{array}$ & $\begin{array}{c}\text { Standard } \\
\text { Deviation } \\
\left(\mathrm{mg} / \mathrm{m}^{3}\right)\end{array}$ \\
\hline 55 & Dodecane, 3-methyl- & $17312-57-1$ & 0.54 & 0.06 \\
56 & Tetradecane, 4-methyl- & $25117-24-2$ & 3.13 & 0.33 \\
57 & 1,1'-Bicyclohexyl, 2-methyl-, cis- & $50991-08-7$ & 0.12 & 0.02 \\
58 & 3-Dodecanone & $1534-27-6$ & 0.31 & 0.05 \\
59 & Tetradecane & $629-59-4$ & 3.61 & 0.57 \\
60 & Tridecane, 4,8-dimethyl- & $55030-62-1$ & 0.57 & 0.09 \\
61 & Cyclohexane, 1,1,3-trimethyl- & $54965-05-8$ & 0.74 & 0.09 \\
62 & 2-(3-methylpentyl)- & & & 0.10 \\
63 & 6-Tridecanone & $544-76-3$ & 0.55 & 0.07 \\
64 & 3-Tridecanone & $22026-12-6$ & 0.31 & 0.06 \\
65 & Pentadecane & $1534-26-5$ & 0.17 & 0.02 \\
66 & Benzenesulfonamide, N-butyl- & $629-62-9$ & 0.16 & 0.088 \\
\hline \hline
\end{tabular}

$1 \mathrm{CAS}=$ Chemical Abstract Service.

2 Average of $3,200 \mathrm{ml}$ TST samples by ORNL, values listed are estimates. 
Table 4-10

Tank BX-104 Tentatively Identified Organic Compounds in TST Samples Sorted Alphanumerically --

Analyses by Oak Ridge National Laboratory

\begin{tabular}{|c|c|c|c|c|}
\hline$\underset{\#}{\text { Cmpd }}$ & Compound & $\begin{array}{l}\text { CAS }^{1} \\
\text { Number }\end{array}$ & $\begin{array}{l}\text { Average }^{2} \\
\left(\mathrm{mg} / \mathrm{m}^{3}\right)\end{array}$ & $\begin{array}{l}\text { Standard } \\
\text { Deviation } \\
\left(\mathrm{mg} / \mathrm{m}^{3}\right)\end{array}$ \\
\hline 3 & 1-Propanol & $71-23-8$ & 0.48 & 0.02 \\
\hline 20 & 1-Octanol & $111-87-5$ & 0.17 & 0.02 \\
\hline 11 & 1-Hexanol & $111-27-3$ & 0.17 & 0.03 \\
\hline 8 & 1-Pentanol & $71-41-0$ & 0.062 & 0.110 \\
\hline 15 & 1-Heptanol & $111-70-6$ & 0.052 & 0.090 \\
\hline 17 & 1-Hexanol, 2-ethyl- & $104-76-7$ & 0.23 & 0.04 \\
\hline 57 & 1,1'-Bicyciohexyl, 2-methyl-, cis- & 50991-08-7 & 0.12 & 0.02 \\
\hline 7 & 1H-Pyrazole, 3-methyl- & $1453-58-3$ & 0.23 & 0.05 \\
\hline 14 & 2-Heptanone, 6-methyl- & $928-68-7$ & 0.59 & 0.08 \\
\hline 21 & 2-Nonanone & $821-55-6$ & 0.046 & 0.080 \\
\hline 19 & 2-Heptanone, 6-methyl- & $928-68-7$ & 0.15 & 0.02 \\
\hline 4 & 2-Butanone & $78-93-3$ & 0.26 & 0.01 \\
\hline 46 & $\begin{array}{l}2(3 \mathrm{H}) \text {-Benzofuranone, } 3 a, 4,5,6- \\
\text { tetrahydro-trimethyl- }\end{array}$ & $16778-26-0$ & 0.30 & 0.03 \\
\hline 47 & 3-Undecanone & $2216-87-7$ & 0.30 & 0.11 \\
\hline 58 & 3-Dodecanone & $1534-27-6$ & 0.31 & 0.05 \\
\hline 12 & 3-Heptanone & $106-35-4$ & 0.54 & 0.05 \\
\hline 64 & 3-Tridecanone & $1534-26-5$ & 0.17 & 0.06 \\
\hline 32 & 4-Undecene, 6-methyl- & & 0.24 & 0.01 \\
\hline 38 & 4-Nonene, 5-butyl- & $7367-38-6$ & 0.085 & 0.074 \\
\hline 63 & 6-Tridecanone & $22026-12-6$ & 0.31 & 0.07 \\
\hline 66 & Benzenesulfonamide, $\mathrm{N}$-butyl- & $3622-84-2$ & 0.097 & 0.088 \\
\hline 50 & C3-Decahydronaphthalene & & 0.24 & 0.03 \\
\hline 40 & C6-Cyclohexane & & 1.77 & 0.16 \\
\hline 53 & C7-Cyclohexane & & 1.07 & 0.07 \\
\hline 36 & Cyclododecane & $294-62-2$ & 0.16 & 0.01 \\
\hline 23 & Cyclohexane, pentyl- & $4292-92-6$ & 0.13 & 0.11 \\
\hline
\end{tabular}




\begin{tabular}{|c|c|c|c|c|}
\hline$\underset{\#}{\text { Cmpd }}$ & Compound & $\begin{array}{l}\text { CAS }^{1} \\
\text { Number }\end{array}$ & $\begin{array}{l}\text { Average } \\
\left(\mathrm{mg} / \mathrm{m}^{3}\right)\end{array}$ & $\begin{array}{l}\text { Standard } \\
\text { Deviation } \\
\left(\mathrm{mg} / \mathrm{m}^{3}\right)\end{array}$ \\
\hline 45 & Cyclohexane, 1,1,3,5-tetramethyl- & $50876-32-9$ & 0.15 & 0.27 \\
\hline 43 & Cyclohexane, (2,2-dimethylcyclopentyl)- & $61142-23-2$ & 0.31 & 0.02 \\
\hline 30 & Cyclohexane, 1-ethyl-4-methyl-, cis- & $4926-78-7$ & 0.57 & 0.06 \\
\hline 61 & $\begin{array}{l}\text { Cyclohexane, 1,1,3-trimethyl- } \\
\text { 2-(3-methylpentyl)- }\end{array}$ & $54965-05-8$ & 0.74 & 0.09 \\
\hline 39 & Cyclohexane, 2-butyl-1,1,3-trimethyl- & $54676-39-0$ & 0.84 & 0.09 \\
\hline 51 & Cyclohexane,1,3,5-trimethyl-2-octadecyl- & $55282-34-3$ & 0.048 & 0.084 \\
\hline 16 & Cyclotetrasiloxane, octamethyi- & $556-67-2$ & 0.21 & 0.20 \\
\hline 9 & Cyclotrisiloxane, hexamethyl- & $541-05-9$ & 0.48 & 0.16 \\
\hline 35 & Decane, 2,3,7-trimethyl- & $62238-13-5$ & 0.16 & 0.02 \\
\hline 29 & Decane, 2,4,6-trimethyl- & $62108-27-4$ & 0.20 & 0.02 \\
\hline 28 & Decane, 3,8-dimethyl- & $17312-55-9$ & 0.30 & 0.04 \\
\hline 42 & Decane, 2,3,7-trimethyl- & $62238-13-5$ & 0.85 & 0.11 \\
\hline 52 & Dodecane, 2,5-dimethyl- & $56292-65-0$ & 0.061 & 0.100 \\
\hline 34 & Dodecane, 3-methyl- & $17312-57-1$ & 0.46 & 0.05 \\
\hline 55 & Dodecane, 3-methyl- & $17312-57-1$ & 0.54 & 0.06 \\
\hline 2 & Ethanol and butane, 2-methyl- & & 0.20 & 0.18 \\
\hline 6 & Furan, tetrahydro- & $109-99-9$ & 0.55 & 0.07 \\
\hline 62 & Hexadecane & $544-76-3$ & 0.55 & 0.10 \\
\hline 1 & n-Butane & $106-97-8$ & 0.80 & 0.16 \\
\hline 24 & Naphthalene, decahydro-2-methyl- & $2958-76-1$ & 0.037 & 0.064 \\
\hline 37 & Naphthalene, decahydro-2, 3-dimethyl- & $1008-80-6$ & 0.039 & 0.068 \\
\hline 31 & Naphthalene, decahydro-2, 6-dimethyl- & $1618-22-0$ & 0.039 & 0.068 \\
\hline 13 & Nitric acid, pentyl ester & $1002-16-0$ & 0.049 & 0.085 \\
\hline 10 & Nitric acid, butyl ester & $928-45-0$ & 0.17 & 0.01 \\
\hline 5 & Nitrous acid, butyl ester & $544-16-1$ & 0.062 & 0.110 \\
\hline 22 & Octane, 6-ethyi-2-methyl- & $62016-19-7$ & 0.17 & 0.02 \\
\hline 44 & Octane, 2,3,7-trimethy!- & $62016-34-6$ & 3.05 & 0.32 \\
\hline 18 & Oxirane, 2-ethyl-3-propyl-, cis- & $56052-94-9$ & 0.16 & 0.02 \\
\hline
\end{tabular}


WHC-SD-WM-ER-439 REV. 1

\begin{tabular}{rlrrr}
\hline $\begin{array}{c}\text { Cmpd } \\
\#\end{array}$ & Compound & $\begin{array}{c}\text { CAS }^{1} \\
\text { Number }\end{array}$ & $\begin{array}{c}\text { Average } \\
\left(\mathrm{mg} / \mathrm{m}^{3}\right)\end{array}$ & $\begin{array}{c}\text { Standard } \\
\text { Deviation } \\
\left(\mathrm{mg} / \mathrm{m}^{3}\right)\end{array}$ \\
\hline \hline 65 & Pentadecane & $629-62-9$ & 0.16 & 0.02 \\
56 & Tetradecane, 4-methyl- & $25117-24-2$ & 3.13 & 0.33 \\
59 & Tetradecane & $629-59-4$ & 3.61 & 0.57 \\
48 & Tridecane, 7-methyl- & $26730-14-3$ & 0.26 & 0.02 \\
54 & Tridecane, 2-methyl- & $1560-96-9$ & 0.48 & 0.04 \\
60 & Tridecane, 4,8-dimethyl- & $55030-62-1$ & 0.57 & 0.09 \\
26 & Undecane, 4-methyl- & $2980-69-0$ & 0.21 & 0.02 \\
25 & Undecane, 6-methyl- & $17302-33-9$ & 0.36 & 0.05 \\
27 & Undecane, 2-methyl- & $7045-71-8$ & 0.41 & 0.05 \\
41 & Undecane, 2,3-dimethyl- & $17312-77-5$ & 0.78 & 0.11 \\
49 & Undecane, 5,5-dimethyl- & $17312-73-1$ & 1.42 & 0.14 \\
33 & Undecane, 2,6-dimethyl- & $17301-23-4$ & 2.17 & 0.19 \\
\hline \hline
\end{tabular}

$1 \mathrm{CAS}=$ Chemical Abstract Service.

2 Average of 3,200 $\mathrm{ml}$ TST samples by ORNL, values listed are estimates. 
WHC-SD-WM-ER-439 REV. 1

Table 4-11

Tank BX-104 Tentatively Identified Organic Compounds in TST Samples Sorted by Estimated Concentration -.

Analyses by Oak Ridge National Laboratory

\begin{tabular}{|c|c|c|c|c|}
\hline$\underset{\#}{\text { Cmpd }}$ & Compound & $\begin{array}{l}\text { CAS }^{1} \\
\text { Number }\end{array}$ & $\begin{array}{l}\text { Average }^{2} \\
\left(\mathrm{mg} / \mathrm{m}^{3}\right)\end{array}$ & $\begin{array}{l}\text { Standard } \\
\text { Deviation } \\
\left(\mathrm{mg} / \mathrm{m}^{3}\right)\end{array}$ \\
\hline 59 & Tetradecane & $629-59-4$ & 3.61 & 0.57 \\
\hline 56 & Tetradecane, 4-methyl- & $25117-24-2$ & 3.13 & 0.33 \\
\hline 44 & Octane, 2,3,7-trimethyl- & $62016-34-6$ & 3.05 & 0.32 \\
\hline 33 & Undecane, 2,6-dimethyl- & $17301-23-4$ & 2.17 & 0.19 \\
\hline 40 & C6-Cyclohexane & & 1.77 & 0.16 \\
\hline 49 & Undecane, 5,5-dimethyl- & $17312-73-1$ & 1.42 & 0.14 \\
\hline 53 & C7-Cyclohexane & & 1.07 & 0.07 \\
\hline 42 & Decane, 2,3,7-trimethyl- & $62238-13-5$ & 0.85 & 0.11 \\
\hline 39 & Cyclohexane, 2-butyl-1,1,3-trimethyl- & $54676-39-0$ & 0.84 & 0.09 \\
\hline 1 & n-Butane & $106-97-8$ & 0.80 & 0.16 \\
\hline 41 & Undecane, 2,3-dimethyl- & $17312-77-5$ & 0.78 & 0.11 \\
\hline 61 & $\begin{array}{l}\text { Cyclohexane, 1,1,3-trimethyl- } \\
\text { 2-(3-methyipentyl)- }\end{array}$ & $54965-05-8$ & 0.74 & 0.09 \\
\hline 14 & 2-Heptanone, 6-methyl & $928-68-7$ & 0.59 & 0.08 \\
\hline 30 & Cyclohexane, 1-ethyl-4-methyl-, cis- & $4926-78-7$ & 0.57 & 0.06 \\
\hline 60 & Tridecane, 4,8-dimethyl- & $55030-62-1$ & 0.57 & 0.09 \\
\hline 6 & Furan, tetrahydro- & $109-99-9$ & 0.55 & 0.07 \\
\hline 62 & Hexadecane & $544-76-3$ & 0.55 & 0.10 \\
\hline 55 & Dodecane, 3-methyl- & $17312-57-1$ & 0.54 & 0.06 \\
\hline 12 & 3-Heptanone & $106-35-4$ & 0.54 & 0.05 \\
\hline 3 & 1-Propanol & $71-23-8$ & 0.48 & 0.02 \\
\hline 9 & Cyclotrisiloxane, hexamethyl- & $541-05-9$ & 0.48 & 0.16 \\
\hline 54 & Tridecane, 2-methyl- & $1560-96-9$ & 0.48 & 0.04 \\
\hline 34 & Dodecane, 3-methyl- & $17312-57-1$ & 0.46 & 0.05 \\
\hline 27 & Undecane, 2-methyl- & $7045-71-8$ & 0.41 & 0.05 \\
\hline 25 & Undecane, 6-methyl- & $17302-33-9$ & 0.36 & 0.05 \\
\hline 58 & 3-Dodecanone & $1534-27-6$ & 0.31 & 0.05 \\
\hline
\end{tabular}




\begin{tabular}{|c|c|c|c|c|}
\hline$\underset{\#}{\text { Cmpd }}$ & Compound & $\begin{array}{l}\text { CAS }^{1} \\
\text { Number }\end{array}$ & $\begin{array}{l}\text { Average }^{2} \\
\left(\mathrm{mg} / \mathrm{m}^{3}\right)\end{array}$ & $\begin{array}{c}\text { Standard } \\
\text { Deviation } \\
\left(\mathrm{mg} / \mathrm{m}^{3}\right)\end{array}$ \\
\hline 43 & Cyclohexane, (2,2-dimethylcyclopentyl)- & $61142-23-2$ & 0.31 & 0.02 \\
\hline 63 & 6-Tridecanone & $22026-12-6$ & 0.31 & 0.07 \\
\hline 28 & Decane, 3,8-dimethyl- & $17312-55-9$ & 0.30 & 0.04 \\
\hline 46 & $\begin{array}{l}\text { 2(3H)-Benzofuranone, } 3 \mathrm{a} \\
4,5,6 \text { - tetrahydro-trimethyl- }\end{array}$ & $16778-26-0$ & 0.30 & 0.03 \\
\hline 47 & 3-Undecanone & $2216-87-7$ & 0.30 & 0.11 \\
\hline 4 & 2-Butanone & $78-93-3$ & 0.26 & 0.01 \\
\hline 48 & Tridecane, 7-methyl- & $26730-14-3$ & 0.26 & 0.02 \\
\hline 32 & 4-Undecene, 6-methyl- & & 0.24 & 0.01 \\
\hline 50 & C3-Decahydronaphthalene & & 0.24 & 0.03 \\
\hline 17 & 1-Hexanol, 2-ethyl- & $104-76-7$ & 0.23 & 0.04 \\
\hline 7 & 1H-Pyrazole, 3-methyl- & $1453-58-3$ & 0.23 & 0.05 \\
\hline 26 & Undecane, 4-methyl- & $2980-69-0$ & 0.21 & 0.02 \\
\hline 16 & Cyclotetrasiloxane, octamethyl- & $556-67-2$ & 0.21 & 0.20 \\
\hline 2 & Ethanol and butane, 2-methyl- & & 0.20 & 0.18 \\
\hline 29 & Decane, 2,4,6-trimethyl- & $62108-27-4$ & 0.20 & 0.02 \\
\hline 20 & 1-Octanol & $111-87-5$ & 0.17 & 0.02 \\
\hline 22 & Octane, 6-ethyl-2-methyl- & $62016-19-7$ & 0.17 & 0.02 \\
\hline 10 & Nitric acid, butyl ester & $928-45-0$ & 0.17 & 0.01 \\
\hline 11 & 1-Hexanol & $111-27-3$ & 0.17 & 0.03 \\
\hline 64 & 3-Tridecanone & $1534-26-5$ & 0.17 & 0.06 \\
\hline 65 & Pentadecane & $629-62-9$ & 0.16 & 0.02 \\
\hline 36 & Cyclododecane & $294-62-2$ & 0.16 & 0.01 \\
\hline 18 & $\begin{array}{l}\text { Oxirane, 2-ethyl- } \\
\text { 3-propyl-, cis- }\end{array}$ & $56052-94-9$ & 0.16 & 0.02 \\
\hline 35 & Decane, 2,3,7-trimethyl- & $62238-13-5$ & 0.16 & 0.02 \\
\hline 45 & Cyclohexane, 1,1,3,5-tetramethyl- & $50876-32-9$ & 0.15 & 0.27 \\
\hline 19 & 2-Heptanone, 6-methyl- & $928-68-7$ & 0.15 & 0.02 \\
\hline 23 & Cyclohexane, pentyl- & $4292-92-6$ & 0.13 & 0.11 \\
\hline 57 & 1,1'-Bicyclohexyl, 2-methyl-, cis- & 50991-08-7 & 0.12 & 0.02 \\
\hline
\end{tabular}


WHC-SD-WM-ER-439 REV. 1

\begin{tabular}{clrrr}
\hline $\begin{array}{c}\text { Cmpd } \\
\#\end{array}$ & Compound & $\begin{array}{c}\text { CAS' } \\
\text { Number }\end{array}$ & $\begin{array}{c}\text { Average } \\
\left(\mathrm{mg}^{2} \mathrm{~m}^{3}\right)\end{array}$ & $\begin{array}{c}\text { Standard } \\
\text { Deviation } \\
\left(\mathrm{mg} / \mathrm{m}^{3}\right)\end{array}$ \\
\hline \hline 66 & Benzenesulfonamide, N-butyl- & $3622-84-2$ & 0.097 & 0.088 \\
38 & 4-Nonene, 5-butyl- & $7367-38-6$ & 0.085 & 0.074 \\
5 & Nitrous acid, butyl ester & $544-16-1$ & 0.062 & 0.110 \\
8 & 1-Pentanol & $71-41-0$ & 0.062 & 0.110 \\
52 & Dodecane, 2,5-dimethyl- & $56292-65-0$ & 0.061 & 0.100 \\
15 & 1-Heptanol & $111-70-6$ & 0.052 & 0.090 \\
13 & Nitric acid, pentyl ester & $1002-16-0$ & 0.049 & 0.085 \\
51 & Cyciohexane, 1,3,5-trimethyl-2-octadecyl- & $55282-34-3$ & 0.048 & 0.084 \\
21 & 2-Nonanone & $821-55-6$ & 0.046 & 0.080 \\
31 & Naphthalene, decahydro-2, 6-dimethyl- & $1618-22-0$ & 0.039 & 0.068 \\
37 & Naphthalene, decahydro-2; 3-dimethyl- & $1008-80-6$ & 0.039 & 0.068 \\
24 & Naphthalene, decahydro-2-methyl- & $2958-76-1$ & 0.037 & 0.064 \\
\hline \hline Sum of tentatively identified compounds: & & 33.63 & \\
\hline \hline
\end{tabular}

$1 \mathrm{CAS}=$ Chemical Abstract Service.

2 Average of $3,200 \mathrm{ml}$ TST samples by ORNL, values listed are estimates. 
